Revista Eletrônica de Direito Processual - REDP.

Rio de Janeiro. Ano 15. Volume 22. Número 2. Maio a Agosto de 2021

Periódico Quadrimestral da Pós-Graduação Stricto Sensu em Direito Processual da UERJ

Patrono: José Carlos Barbosa Moreira (in mem.). ISSN 1982-7636. pp. 268-301

www.redp.uerj.br

\title{
A DECISÃO DE PRONÚNCIA COMO FILTRO PROCESSUAL: REQUISITOS FORMAIS E CRITÉRIOS DE EFETIVIDADE ${ }^{1}$
}

\section{THE INDICTMENT DECISION AS A PROCEDURAL FILTER: LEGAL REQUIREMENTS AND EFFECTIVENESS CRITERIA}

Fernando Martinho de Barros Penteado Mestre em direito processual penal pela Pontifícia Universidade Católica de São Paulo. Especialista em direito processual penal pela Escola Paulista da Magistratura. Juiz de Direito no Estado de São Paulo. Santos, São Paulo, Brasil. Email: fernandombpenteado@gmail.com. Currículo lattes: http://lattes.cnpq.br/1830762220815573. ORCID: 00000002-0455-6108. E mail: fernandombpenteado@gmail.com

RESUMO: Este artigo analisa a decisão de pronúncia e o juízo de admissibilidade positivo da acusação emitido na primeira etapa do procedimento do júri. A pronúncia atua como um filtro processual e visa reduzir o risco de condenações infundadas em plenário. A partir da revisão bibliográfica, o trabalho visa responder como essa função de garantia pode ser eficientemente alcançada. O resultado aponta a necessidade de compreensão adequada dos requisitos formais da pronúncia e a adoção de critérios de efetividade, como o contraditório, a imediação e o conceito dos standards de provas como auxílio hermenêutico na definição da suficiência dos indícios de autoria.

PALAVRAS-CHAVE: tribunal do júri; pronúncia; contraditório; imediação; standards de provas

ABSTRACT: This work analyzes the indictment decision carried out in the first stage of the jury procedure. The indictment decision acts as a procedural filter reducing the risk of wrongful convictions by the jury. Through bibliographic review, the work will address the

\footnotetext{
${ }^{1}$ Artigo recebido em 28/04/2020 e aprovado em 16/12/2020.
} 
Revista Eletrônica de Direito Processual - REDP.

Rio de Janeiro. Ano 15. Volume 22. Número 2. Maio a Agosto de 2021

Periódico Quadrimestral da Pós-Graduação Stricto Sensu em Direito Processual da UERJ

Patrono: José Carlos Barbosa Moreira (in mem.). ISSN 1982-7636. pp. 268-301

www.redp.uerj.br

problem of how this expected function can be fully achieved. In order to perform substantially, it is necessary to properly understand the legal requirements of the indictment decision and to adopt certain effectiveness criteria, such as the adversarial principle, immediacy and the support in the concept of standards of proof.

KEYWORDS: jury; indictment; adversarial principle; inmediacy; standards of proof

\section{Introdução}

Nos termos do art. $5^{\circ}$, inc. XXXVIII, da Constituição de 1988 , a instituição do júri é reconhecida constitucionalmente e tem competência para o julgamento dos crimes dolosos contra a vida.

Por sua vez, o art. 74, $\S 1^{\circ}$, do Código de Processo Penal atribui ao tribunal do júri o julgamento dos delitos previstos nos arts. $121, \S \S 1^{\circ}$ e $2^{\circ}$ (homicídio doloso), 122, parágrafo único (induzimento, instigação ou auxílio a suicídio por terceiro), 123 (infanticídio), 124, 125, 126 e 127 (aborto praticado pela gestante ou por terceiro com ou sem consentimento), todos do Código Penal. ${ }^{2}$

A legislação processual prevê um procedimento bifásico, estabelecendo uma etapa judicial prévia com ampla produção de provas destinada a realizar o exame de admissibilidade da acusação.

Esse iter prévio, chamado de juízo da acusação, ${ }^{3}$ atua com a finalidade de impedir que acusações infundadas sejam julgadas em plenário, reduzindo o risco de decisões arbitrárias. Destina-se, pois, a verificar se há lastro probatório razoável nos termos exigidos em lei para a instauração da fase seguinte.

\footnotetext{
${ }^{2}$ A Lei 13.968, de 26 de dezembro de 2019, alterou o art. 122 do Código Penal e acrescentou o crime de induzimento, instigação e auxílio à automutilação.

${ }^{3}$ Também conhecido como judicium accusationis, juízo de formação da culpa ou sumário da culpa. Explica Antonio Scarance Fernandes que o sumário da culpa é uma fase intermediária situada entre a investigação preliminar e o julgamento: "Nos procedimentos que adotaram o sistema misto, além das primeiras atividades destinadas à colheita de informes a respeito do fato e da autoria, realizavam-se outras, posteriores, para justificar o encaminhamento do processo a julgamento e a prisão da pessoa investigada. O conjunto dessas atividades formava a fase do sumário da culpa ou da instrução provisória" (FERNANDES, Scarance Antonio. Teoria geral do procedimento e o procedimento no processo penal. São Paulo: Revista dos Tribunais, 2005, p. 88). No procedimento do júri brasileiro, o sumário da culpa é a fase intermediária entre a investigação policial e o julgamento em plenário.
} 
Revista Eletrônica de Direito Processual - REDP.

Rio de Janeiro. Ano 15. Volume 22. Número 2. Maio a Agosto de 2021

Periódico Quadrimestral da Pós-Graduação Stricto Sensu em Direito Processual da UERJ

Patrono: José Carlos Barbosa Moreira (in mem.). ISSN 1982-7636. pp. 268-301

www.redp.uerj.br

O juízo da acusação é constituído de duas partes: a instrução preliminar (artigos 406 a 412 do Código de Processo Penal) e a etapa de julgamento subsequente, onde os elementos de prova colhidos são aferidos, podendo ensejar ao final quatro hipóteses decisórias: pronúncia, impronúncia, absolvição sumária ou desclassificação (arts. 413 a 419 do Código de Processo Penal). ${ }^{4}$

A emissão da decisão de pronúncia significa que o juízo de admissibilidade da acusação foi positivo e enseja o julgamento em plenário perante o conselho de sentença.

Por isso, diz-se que a pronúncia constitui "um ato preventivo de preparação e segurança do ingresso na fase de julgamento final" onde o juiz exerce "função saneadora" e de verificação "da probabilidade de ser exata a imputação deduzida na denúncia", , sempre de forma a "preservar a inocência contra as acusações infundadas e o organismo judiciário contra o custo e a inutilidade em que estas redundariam". 7

As particulidades do tribunal do júri, notadamente a atuação de juízes leigos, a soberania dos veredictos e a não exigência de motivação, legitimam a instituição de um controle judicializado prévio da acusação. Entretanto, questiona-se em que grau o juízo de admissibilidade positivo da acusação realizado na pronúncia constitui, no plano formal e material, uma garantia efetiva ao acusado contra excessos acusatórios.

Assim, o objetivo deste trabalho é verificar criticamente o juízo de admissibilidade realizado na pronúncia a partir de seus requisitos formais e de critérios materiais aptos a concretizar a função de juízo avançado e qualificado da acusação.

Justifica-se o estudo do tema pelo fato de que, não compreendidos os requisitos formais em sua exata extensão e olvidados certos parâmetros de efetividade, a pretendida função de garantia tende a não se materializar, tornando a primeira etapa do procedimento do júri meramente burocrática e carente de sentido.

\footnotetext{
${ }^{4}$ Não obstante, é comum a compreensão de que a expressão “instrução preliminar" seja sinônima do próprio juízo da acusação. Nesse sentido: IRIBURE JÚNIOR, Hamilton da Cunha. A pronúncia no procedimento do tribunal do júri brasileiro. 562f. Tese (Doutorado em Direito). Pontifícia Universidade Católica de São Paulo. São Paulo, 2008, p. 288.

${ }^{5}$ AQUINO, Álvaro Antônio Sagulo Borges de. A função garantidora da pronúncia. Rio de Janeiro: Lumen Juris, 2004, p. 105-106.

${ }^{6}$ MARQUES, José Frederico. A instituição do júri. São Paulo: Saraiva, 1963, p. 57.

${ }^{7}$ ALMEIDA, Joaquim Canuto Mendes de. Princípios fundamentais do processo penal. São Paulo: Revista dos Tribunais, 1973, p. 17.
} 
Revista Eletrônica de Direito Processual - REDP.

Rio de Janeiro. Ano 15. Volume 22. Número 2. Maio a Agosto de 2021

Periódico Quadrimestral da Pós-Graduação Stricto Sensu em Direito Processual da UERJ

Patrono: José Carlos Barbosa Moreira (in mem.). ISSN 1982-7636. pp. 268-301

www.redp.uerj.br

$\mathrm{O}$ presente estudo está estruturado em quatro partes. $\mathrm{Na}$ primeira, o recebimento da denúncia será analisado, pois assim como a pronúncia, constitui um juízo de admissibilidade, importando seu lineamento teórico para posterior comparação e distinção.

$\mathrm{Na}$ segunda parte, abordar-se-ão os requisitos formais da pronúncia e a sua exata significação. Em seguida, no terceiro seguimento, buscar-se-á demonstrar que a função de filtro processual depende também de certas premissas qualitativas extraíveis sistemicamente da lei processual, cuja combinação com os requisitos formais produz efetividade à função de garantia.

$\mathrm{Na}$ quarta e derradeira parte, o modelo de pronúncia moldado a partir da integração dos requisitos formais e dos parâmetros materiais de efetividade será confrontado com o princípio do in dubio pro societate.

\section{O duplo juízo de admissibilidade da acusação no procedimento dos crimes de competência do Tribunal do Júri}

No procedimento escalonado do júri, a acusação é de formação progressiva. ${ }^{8}$ Além do juízo de admissibilidade elaborado no sumário da culpa, a acusação igualmente se submete a um exame prévio, consistente no recebimento da denúncia. Esse duplo juízo de admissibilidade caracteriza a aludida progressividade na formação da acusação.

O recebimento da denúncia segue o disposto no art. 395 do Código de Processo Penal, cuja disciplina impõe a rejeição quando for manifestamente inepta, faltar pressuposto processual ou condição da ação penal, ou ainda, carecer de justa causa para o exercício da ação penal. No estudo comparativo com a pronúncia, interessa especificamente a justa causa.

Segundo Maria Thereza Rocha de Assis Moura, justa causa são os fundamentos de fato e de direito que embasam a acusação. Quanto ao fundamento de direito, este pressupõe que a ordem jurídica aceite a limitação à liberdade jurídica, enquanto que o fundamento de fato pressupõe que a denúncia guarde fidelidade com os elementos de informação obtidos

\footnotetext{
${ }^{8}$ MARQUES, José Frederico. A instituição do júri. São Paulo: Saraiva, 1963, p. 57.
} 
Revista Eletrônica de Direito Processual - REDP.

Rio de Janeiro. Ano 15. Volume 22. Número 2. Maio a Agosto de 2021

Periódico Quadrimestral da Pós-Graduação Stricto Sensu em Direito Processual da UERJ

Patrono: José Carlos Barbosa Moreira (in mem.). ISSN 1982-7636. pp. 268-301

www.redp.uerj.br

na investigação preliminar e relacionados com a existência de fato típico e ilícito, assim como indícios suficientes de autoria e um mínimo de culpabilidade. ${ }^{9}$

O regular exercício da ação penal depende da justa causa, isto é, que venha lastreada em elementos que demonstrem não ser a acusação temerária, correspondendo a um suporte probatório mínimo relacionado com indícios de autoria, existência material de uma conduta típica e relativa demonstração da ilicitude e culpabilidade. ${ }^{10}$

Portanto, no que concerne à justa causa, o recebimento da denúncia exige a demonstração preliminar do cometimento de um fato criminoso e indícios de autoria, assemelhando-se aos requisitos definidos no art. 413 do Código de Processo Penal.

Em ambos os casos, a discussão gravita em torno da admissibilidade da acusação. ${ }^{11}$ Apesar disso, os distintos momentos processuais em que proferidas tais decisões resultam em condições diferentes de cada análise.

O recebimento da denúncia implica uma análise inicial dos componentes da justa causa a partir dos elementos produzidos na etapa de investigação. Aferidos positivamente, legitima-se o início da persecução penal em juízo, inaugurando-se uma fase instrutória ampla e igualmente voltada a aferir a acusação, agora numa perspectiva judicializada.

Comparativamente com o recebimento da denúncia, a pronúncia configura um “juízo avançado sobre a admissibilidade da acusação", cuja emissão sinaliza que a proposta acusatória apresentada com a denúncia teve evolução consistente com o observado no curso da instrução preliminar. ${ }^{12}$

\section{Pronúncia e requisitos formais}

\footnotetext{
${ }^{9}$ MOURA, Maria Thereza Rocha de Assis. Justa causa para a ação penal. Doutrina e jurisprudência. São Paulo: Revista dos Tribunais, 2001, p. 291.

${ }^{10}$ JARDIM, Afrânio Silva. Direito processual penal. 5. ed. Rio de Janeiro: Forense, 1995, p. 147.

${ }^{11}$ Para Maria Lúcia Karam, a decisão de pronúncia tem a natureza do recebimento da denúncia, já que ambas decisões apreciam a existência de justa causa (KARAM, Maria Lúcia. A admissibilidade da acusação e a pronúncia. Fascículos de Ciências Penais. Porto Alegre, v. 6, n. 1, jan./fev. 1993, p. 131. Disponível em: http://201.23.85.222/biblioteca/index.asp?codigo_sophia=52152. Acesso em: 13 de outubro de 2019).

${ }^{12}$ NOGUEIRA, Rafael Fecury. A decisão de pronúncia no processo penal brasileiro: valoração da prova e limites à motivação. Rio de Janeiro: Lumen Juris, 2018, p. 70.
} 
Revista Eletrônica de Direito Processual - REDP.

Rio de Janeiro. Ano 15. Volume 22. Número 2. Maio a Agosto de 2021

Periódico Quadrimestral da Pós-Graduação Stricto Sensu em Direito Processual da UERJ

Patrono: José Carlos Barbosa Moreira (in mem.). ISSN 1982-7636. pp. 268-301

www.redp.uerj.br

Nos exatos termos do art. 413, caput, do Código de Processo Penal, o juiz pronunciará o acusado se convencido da materialidade do fato e da existência de indícios suficientes de autoria ou de participação.

A pronúncia possui natureza jurídica de decisão interlocutória que encerra a primeira fase do procedimento do júri e inicia a etapa de julgamento em plenário.

A fundamentação fica limitada à indicação da materialidade do fato e existência dos indícios de autoria, com a declaração do dispositivo legal e especificação das qualificadoras e causas de aumento de pena, ${ }^{13}$ além da forma consumada ou tentada. ${ }^{14}$

Deve haver moderação e sobriedade nos termos e expressões empregadas na pronúncia para não influenciar o ânimo dos jurados na fase subsequente. ${ }^{15}$

Admitida a acusação pela pronúncia, os jurados não sofrem limitação em sua competência. O fato do julgamento em plenário ser contrário ao juízo realizado na pronúncia, eventualmente negando a materialidade, autoria ou qualificadoras, significa apenas a concretização da soberania dos veredictos assegurada constitucionalmente e não infirma a lógica legal de estabelecer um controle preliminar da acusação pelo juiz togado.

\subsection{Probabilidade da autoria e certeza do fato}

A emissão da pronúncia significa que o exame da admissibilidade realizado no juízo da acusação foi positivo. Para consecução desse objetivo, a lei estabelece como requisitos formais a materialidade do fato e existência de indícios suficientes de autoria.

No que concerne aos indícios de autoria ou participação, não se exige um juízo de certeza, mas a probabilidade sobre o cometimento da infração penal.

\footnotetext{
13 As agravantes e atenuantes não devem ser referidas por consubstanciarem matéria afeta à aplicação da pena. Por sua vez, o art. $7^{\circ}$ da Lei de Introdução ao Código de Processo Penal (Dec-lei 3.931/41) veda a referência das causas de diminuição na pronúncia.

14 Lembra James Tubenchlak que no crime tentado devem ser explicitados os indícios relativos às circunstâncias impeditivas da consumação (TUBENCHLAK, James. Tribunal do júri. Contradições e soluções. 4. ed. São Paulo: Saraiva, 1994, p. 67).

${ }^{15}$ Rafael Fecury Nogueira anota que há uma tensão constante entre a necessária fundamentação para impedir acusações infundadas e o excesso de linguagem para evitar julgamentos antecipados e a influência dos jurados na fase posterior (NOGUEIRA, Rafael Fecury. A decisão de pronúncia no processo penal brasileiro: valoração da prova e limites à motivação. Rio de Janeiro: Lumen Juris, 2018, p. 207).
} 
Revista Eletrônica de Direito Processual - REDP.

Rio de Janeiro. Ano 15. Volume 22. Número 2. Maio a Agosto de 2021

Periódico Quadrimestral da Pós-Graduação Stricto Sensu em Direito Processual da UERJ

Patrono: José Carlos Barbosa Moreira (in mem.). ISSN 1982-7636. pp. 268-301

www.redp.uerj.br

É importante esclarecer que "indício" não possui sentido unívoco. Numa acepção ainda ligada ao sistema da prova legal, indício "significa prova dotada de eficácia persuasiva atenuada, não sendo apta, por si, a estabelecer a verdade sobre um fato."16

Já numa terminologia mais moderna, indício deve ser compreendido como prova indireta em contraposição à prova direta, "segundo uma distinção que não está fundada na eficácia persuasiva, mas sim na relação entre o fato a ser provado no processo e o objeto da prova." $" 17$

$\mathrm{Na}$ forma proposta no art. 413, caput, do Código de Processo Penal, "indícios" tem o primeiro sentido, ou seja, traduz-se em prova mais tênue (semiplena) ${ }^{18}$ ou "prova levior" ("mais leve"). ${ }^{19}$

Não se trata de exigência legal de prova indireta para a autoria ou que a pronúncia deva se pautar exclusivamente por elementos obtidos na forma do art. 239 do Código de Processo Penal, o que caracterizaria tarifamento indevido e impediria a livre apreciação das provas.

A referida expressão significa, pois, um determinado quantum de prova apto a satisfazer o juízo de probabilidade requerido pela lei processual para a autoria e participação, sem a necessidade de gerar um juízo de certeza. ${ }^{20}$

$\mathrm{Na}$ verdade, pode até haver prova suficiente para a certeza quanto à autoria, mas a lei impõe que o juiz se limite ao âmbito da probabilidade.

A noção de probabilidade, essencial para se entender a pronúncia, deve ser diferenciada de possibilidade. Esclarece Sérgio Pitombo que o juízo possível é o logicamente não contraditório, sem motivos fortes contra ou a favor, ou seja, "Emerge

\footnotetext{
16 GOMES FILHO, Antonio Magalhães. A motivação das decisões penais. São Paulo: Revista dos Tribunais, 2013, p. 137.

17 GOMES FILHO, Antonio Magalhães. A motivação das decisões penais. São Paulo: Revista dos Tribunais, 2013, p. 138, destaque do original.

18 BADARÓ, Gustavo Henrique Righi Ivahy. Ônus da prova no processo penal. São Paulo: Revista dos Tribunais, 2003, p. 278-279.

${ }^{19}$ MARQUES, José Frederico. A instituição do júri. São Paulo: Saraiva, 1963, p. 223.

${ }^{20}$ Discorda-se, portanto, das posições de José Roberto Antonini, que sustenta um juízo de certeza quanto à autoria na pronúncia (ANTONINI, José Roberto. Júri. Garantia individual. Boletim IBCCRIM. São Paulo, v. 18, n. 210, nov. 2010, p. 18) e de César Peres, para quem indícios deve ser interpretado "como sendo estes de tal monta que levariam juiz singular a condenar" (PERES, César. Sentença de pronúncia: in dubio pro societate. Boletim IBCCRIM. São Paulo, v. 12, n. 146, jan. 2005, p. 15).
} 
Revista Eletrônica de Direito Processual - REDP.

Rio de Janeiro. Ano 15. Volume 22. Número 2. Maio a Agosto de 2021

Periódico Quadrimestral da Pós-Graduação Stricto Sensu em Direito Processual da UERJ

Patrono: José Carlos Barbosa Moreira (in mem.). ISSN 1982-7636. pp. 268-301

www.redp.uerj.br

neutral, assim: é possível que o homem seja homicida; mas, é possível que não seja. Aflora como suspeito." 21

Por seu turno, o juízo provável é o verossímil, que parte de razões robustas, mas ainda não decisivas, isto é, "Surge aneutral, assim: é provável que o homem seja homicida, por causa dos meios de prova colhidos ou produzidos; mas, talvez não seja."22

Já para a materialidade do fato, diversamente do que ocorre com a autoria, que se satisfaz com a probabilidade, impõe-se a prova plena, ou seja, a certeza de que o fato existiu. Nesse ponto, não há distinção entre o que é decidido na decisão de pronúncia e na sentença de mérito. ${ }^{23}$

Apesar da expressão legal "materialidade do fato", Aramis Nassif aduz que é mais correto falar em "existência do fato", pois existem fatos que não deixam vestígios materiais, como a hipótese de tentativa branca ou incruenta. ${ }^{24}$

Assim como ocorre para a autoria, a fundamentação da pronúncia quanto à existência do fato deve evitar o emprego de termos assertivos e peremptórios, muito embora seja imprescindível a exposição das razões que a fizeram concluir pela certeza.

A Lei 11.689/08 alterou a redação do art. 413 do Código de Processo Penal e substituiu a expressão "materialidade do crime" para "materialidade do fato". Segundo Gustavo Badaró, a modificação foi apenas terminológica, pois apesar de "crime" significar, além da materialidade, o elemento subjetivo, a antijuridicidade e a culpabilidade, a

\footnotetext{
${ }^{21}$ PITOMBO, Sergio Marcos de Moraes. Pronúncia e o "in dubio pro societate". Revista da Escola Paulista da Magistratura. São Paulo, ano 4, n. 1, janeiro/junho de 2003, p. 16.

${ }^{22}$ PITOMBO, Sergio Marcos de Moraes. Pronúncia e o "in dubio pro societate". Revista da Escola Paulista da Magistratura. São Paulo, ano 4, n. 1, janeiro/junho de 2003, p. 16. Semelhantemente, José Frederico Marques explica que "indício suficiente" significa probabilidade suficiente e não mera possibilidade de autoria (MARQUES, Jose Frederico. Encerramento da formação da culpa no processo penal do júri. In: Estudos de direito e processo penal em homenagem a Nelson Hungria. Rio de Janeiro: Forense. 1962, p. 128).

${ }^{23}$ Nesse sentido: ESPÍNOLA FILHO, Eduardo. Código de Processo Penal brasileiro anotado. v. IV. 5. ed. Rio de Janeiro: Editora Rio, 1976, p. 242; MARQUES, José Frederico. A instituição do júri. São Paulo: Saraiva, 1963, p. 225; AQUINO, Álvaro Antônio Sagulo Borges de. A função garantidora da pronúncia. Rio de Janeiro: Lumen Juris, 2004, p. 49. Contrariamente, Aury Lopes Júnior. entende que o juiz não pode afirmar a autoria e nem a materialidade, principalmente em caso de negativa do réu. Assim, o juiz deve se restringir a um juízo de verossimilhança também em relação à materialidade, pois a pronúncia não é momento para a exteriorização de certezas (LOPES JÚNIOR, Aury. Direito processual penal e sua conformidade constitucional. v. 2. 6. ed. Rio de Janeiro: Lumen Juris, 2011, p. 286). Discorda-se, já que a exigência do juízo de certeza para a materialidade não se confunde com o uso de expressões peremptórias pelo juiz para fundamentar a materialidade do fato na pronúncia.

${ }^{24}$ NASSIF, Aramis. O novo júri brasileiro. Porto Alegre: Livraria do Advogado, 2009, p. 56.
} 
Revista Eletrônica de Direito Processual - REDP.

Rio de Janeiro. Ano 15. Volume 22. Número 2. Maio a Agosto de 2021

Periódico Quadrimestral da Pós-Graduação Stricto Sensu em Direito Processual da UERJ

Patrono: José Carlos Barbosa Moreira (in mem.). ISSN 1982-7636. pp. 268-301

www.redp.uerj.br

doutrina já interpretava o termo "crime" do revogado art. 408 como existência da materialidade delitiva, ou seja, apenas o fato material ou o corpo de delito. ${ }^{25}$

Antes da alteração legislativa de 2008, José Frederico Marques propugnava que na pronúncia bastava a prova do fato típico, enquanto que no juízo condenatório era necessário que se provasse a existência do crime na totalidade de seus elementos constitutivos. ${ }^{26}$

Hodiernamente, a doutrina segue correlacionando a materialidade com a morte não natural da vítima por obra de outrem, mas não necessariamente um crime, o que reclamaria a antijuridicidade e a culpabilidade. ${ }^{27}$

Entretanto, Rafael Fecury Nogueira ressalta que é preferível a expressão "crime" a "fato", pois o objeto da pronúncia é um fato típico, ilícito e culpável e, ausente tais elementos, seria caso de absolvição. ${ }^{28}$

$\mathrm{Na}$ verdade, a solução intermediária é mais correta. Com efeito, não se pode excluir por completo a ilicitude e a culpabilidade, assim como o elemento subjetivo do exame realizado na pronúncia. Há inequívoca proximidade da pronúncia com as demais hipóteses decisórias desta fase (impronúncia, desclassificação e absolvição sumária).

Se nesse momento for alcançado um juízo de certeza a respeito da culpa em sentido estrito (e não do dolo) ou da presença de causas excludentes de ilicitude ou culpabilidade, a solução será a desclassificação ou a absolvição sumária, respectivamente.

Como se percebe, agregada à existência do fato, subsiste uma análise residual imprescindível dos demais elementos constitutivos do crime.

Dessa forma, além do juízo de probabilidade explícito exigido para a autoria e do juízo de certeza para o fato em si, a pronúncia pressupõe implicitamente um juízo positivo de possibilidade também em relação ao elemento subjetivo, ilicitude da conduta e culpabilidade. ${ }^{29}$

25 BADARÓ, Gustavo Henrique Righi Ivahy. Tribunal do júri. Lei 11.689, de 09.06.2008. In: MOURA, Maria Thereza Rocha de Assis (coord.). As reformas no processo penal. São Paulo: Revista dos Tribunais, 2008 , p. 75.

${ }^{26}$ MARQUES, José Frederico. A instituição do júri. São Paulo: Saraiva, 1963, p. 225

${ }^{27}$ NUCCI, Guilherme de Souza. Tribunal do júri. 3. ed. São Paulo: Revista dos Tribunais, 2012, p. 81.

${ }^{28}$ NOGUEIRA, Rafael Fecury. A decisão de pronúncia no processo penal brasileiro: valoração da prova e limites à motivação. Rio de Janeiro: Lumen Juris, 2018, p. 78.

${ }^{29}$ Situação semelhante ocorre no art. 314 do Código de Processo Penal. Conforme o preceito, não basta para a decretação da prisão preventiva a situação de necessidade da medida e a prova da existência do crime e indício suficiente de autoria e de perigo gerado pelo estado de liberdade. Em conjunto com tais elementos, 
Revista Eletrônica de Direito Processual - REDP.

Rio de Janeiro. Ano 15. Volume 22. Número 2. Maio a Agosto de 2021

Periódico Quadrimestral da Pós-Graduação Stricto Sensu em Direito Processual da UERJ

Patrono: José Carlos Barbosa Moreira (in mem.). ISSN 1982-7636. pp. 268-301

www.redp.uerj.br

A análise realizada, portanto, é do fato criminoso e não apenas do fato material despido do elemento subjetivo, da ilicitude ou da culpabilidade. ${ }^{30}$ A diferença é de gradação, dando ensejo a um juízo menos rigoroso, ao invés da probabilidade, basta a possibilidade.

Em suma, para a pronúncia deve haver certeza do fato, probabilidade da autoria e possibilidade quanto ao elemento subjetivo e causas de exclusão de ilicitude e culpabilidade.

\subsection{Qualificadoras e causas de aumento de pena}

$\mathrm{O}$ art. $413, \S 1^{\circ}$, do Código de Processo Penal estabelece que as qualificadoras e as causas de aumento de pena devem ser especificadas na pronúncia, logo, ainda que dentro dos limites de um juízo de admissibilidade, exige-se fundamentação.

A regra é válida para as qualificadoras e causas de aumento da parte especial do Código Penal. Já as causas de aumento da parte geral (concurso formal e crime continuado) não comportam exame na pronúncia, pois são circunstâncias que não alteram o tipo penal básico e tem relação com a individualização da pena.

Em geral, a doutrina apregoa a manutenção das qualificadoras, salvo se o juiz não estiver convencido firmemente da inexistência ${ }^{31}$, ou seja, mesmo na dúvida, o juiz deve acolher a qualificadora, ${ }^{32}$ somente as afastando se manifestamente improcedentes ${ }^{33}$,

deve estar presente a aparência da ilicitude da conduta, ou em outras palavras, indicativos que demonstrem a possibilidade de antijuridicidade. Nesse sentido: BADARÓ, Gustavo Henrique Righi Ivahy. Prisão em flagrante delito e liberdade provisória no Código de Processo Penal: origens, mudanças e futuro de um complicado relacionamento. In: MALAN, Diogo; MIRZA, Flávio (coord.). 70 anos do Código de Processo Penal Brasileiro. Balanço e perspectivas de reforma. Rio de Janeiro: Lumen Juris, 2011, p. 178-181.

${ }^{30}$ Segundo Guilherme Brenner Lucchesi, ao longo da persecução penal compete ao órgão acusatório a prova de todos os elementos constitutivos do crime, incluindo o recebimento da denúncia e a pronúncia. O que pode variar é uma menor exigência quanto à carga da prova que lhe compete (LUCCHESI, Guilherme Brenner. O necessário desenvolvimento de standards probatórios compatíveis com o direito processual penal brasileiro. Revista Brasileira de Ciências Criminais. São Paulo, v. 27, n. 156, jun. 2019, p. 179-178).

${ }^{31}$ MARQUES, José Frederico. A instituição do júri. São Paulo: Saraiva, 1963, p. 232,

${ }^{32}$ NORONHA, Edgard Magalhães. Curso de direito processual penal. 16. ed. São Paulo: Saraiva, 1984, p. 248.

${ }^{33}$ MIRABETE, Julio Fabbrini. Processo penal. 14. ed. São Paulo: Atlas, 2003, p. 488; BONFIM, Edilson Mougenot. Júri. Do Inquérito ao plenário. 4. ed. São Paulo: Saraiva, 2012, p. 177. 
Revista Eletrônica de Direito Processual - REDP.

Rio de Janeiro. Ano 15. Volume 22. Número 2. Maio a Agosto de 2021

Periódico Quadrimestral da Pós-Graduação Stricto Sensu em Direito Processual da UERJ

Patrono: José Carlos Barbosa Moreira (in mem.). ISSN 1982-7636. pp. 268-301

www.redp.uerj.br

completamente desvinculadas da prova ${ }^{34}$ ou "quando tenha a instrução demonstrado, com segurança, a carência de suporte". ${ }^{35}$

Em que pese essa forte tendência, o exame das qualificadoras reclama uma análise mais crítica, até mesmo para se questionar que tipo de ônus probatório está se atribuindo ao réu e, simultaneamente, isentando o órgão acusatório de demonstrar o que lhe compete, ainda que em sede de juízo de admissibilidade.

Sobre as qualificadoras, sustenta Nelson Hungria que "De simples accidentalia dos crimes em geral, tais circunstâncias passam a ser essentialia ou elementos constitutivos do homicídio, na sua forma qualificada". ${ }^{36}$

Em sentido semelhante, Márcio Bártoli e André Panzeri ressaltam que, quando agregadas ao homidício, as qualificadoras se tornam elementos constitutivos desse crime e passam a integrar o tipo legal. ${ }^{37}$

Portanto, a qualificadora, rectius, o fato dito qualificante, ao integrar o contexto do fato criminoso imputado ao agente, passa a equivaler à materialidade para os fins do art. 413 do Código de Processo Penal, demandando um juízo de certeza. ${ }^{38}$

Mas isso não é suficiente para esclarecer com precisão a forma de admissão das qualificadoras. A depender das circunstâncias, uma dupla verificação se impõe. ${ }^{39}$

A primeira verificação, aplicável para qualquer caso, refere-se à existência propriamente dita do fato caracterizador da qualificadora, que pode ser o emprego de veneno, fogo, asfixia ou determinada situação apontada como fútil ou torpe que seria

\footnotetext{
${ }^{34}$ NUCCI, Guilherme de Souza. Tribunal do júri. 3. ed. São Paulo: Revista dos Tribunais, 2012, p. 94.

${ }^{35}$ PORTO, Hermínio Alberto Marques. Júri. Procedimento e aspectos do julgamento. 12. ed. São Paulo: Saraiva, 2007, p. 79. No mesmo sentido: GOMES, Márcio Schlee. Júri. Limites constitucionais da pronúncia. Porto Alegre: Sérgio Antonio Fabris Editor, 2010, p. 75-76; 148.

${ }^{36}$ HUNGRIA, Nelson; FRAGOSO, Heleno Claudio. Comentários ao Código Penal. Arts. 121 a 136. Volume V. 5. ed. Rio de Janeiro: Forense, 1979, p. 163, destaque do original.

${ }^{37}$ BÁRTOLI, Márcio Orlando; PANZERI, André. Comentários ao artigo 121. In: FRANCO, Alberto Silva; STOCO, Rui (coord.). Código Penal e sua interpretação. Doutrina e jurisprudência. 8. ed. São Paulo: Revista dos Tribunais, 2007, p. 631.

${ }^{38}$ Nesse sentido: VIDAL, Luís Fernando Camargo de Barros. Homicídio qualificado e procedimento do júri. Revista Brasileira de Ciências Criminais. São Paulo, v. 8, n. 32, out./dez., 2000, p. 107.

${ }^{39}$ Com algumas adaptações e acréscimos, adota-se aqui o procedimento de cognição apresentado por VIDAL, Luís Fernando Camargo de Barros. Homicídio qualificado e procedimento do júri. Revista Brasileira de Ciências Criminais. São Paulo, v. 8, n. 32, out./dez., 2000, p. 108-115. Segundo o autor, em resumo, "há de inicialmente verificar-se a demonstração do fato dito qualificante, sem o que não há que se cogitar da admissibilidade da qualificadora. Seguidamente, o intérprete deve verificar se há vínculo efetivo entre tal fato e a prática do crime, afirmando assim o elemento subjetivo. Por fim, deve o intérprete realizar o juízo de valor acerca deste fato, admitindo-o ou não como qualificante conforme a previsão abstrata da norma." (p. 111).
} 
Revista Eletrônica de Direito Processual - REDP.

Rio de Janeiro. Ano 15. Volume 22. Número 2. Maio a Agosto de 2021

Periódico Quadrimestral da Pós-Graduação Stricto Sensu em Direito Processual da UERJ

Patrono: José Carlos Barbosa Moreira (in mem.). ISSN 1982-7636. pp. 268-301

www.redp.uerj.br

supostamente o motivo da conduta, dentre outros. Em todas essas hipóteses, é imprescindível que o fato imputado na denúncia como qualificante seja demonstrado a partir de um juízo de certeza

Para as qualificadoras objetivas, por exemplo, comprovado plenamente o veneno ou o fogo como causa da morte, a qualificadora deve ser admitida, não havendo espaço para discussão. Por outro lado, ausente prova certa, a qualificadora deve ser rechaçada.

Ainda na primeira etapa, em se tratando de qualificadora subjetiva, uma análise adicional pode ser necessária para aferir o vínculo psíquico entre o fato dito qualificante e a prática do crime, isto é, se o crime foi praticado pelo motivo descrito.

Não pode ser descartada a concorrência de motivos ou o fato alegado como qualificante ter sido na verdade um mero pretexto para o crime, cuja causa real é outra. Nesses casos, não se exige um juízo de certeza da vinculação psíquica entre o fato e o crime, bastando a possibilidade.

Já a segunda verificação configura um juízo de valor que corresponde à subsunção do alegado fato ao tipo legal da qualificadora. Exemplificando, uma vez reconhecido num juízo de certeza que houve uma discussão no dia dos fatos sobre determinado motivo (fato dito qualificante), valora-se se esse fato pode ser considerado como fútil ou torpe, ou ainda, em se tratando de feminicídio, caso o fato tenha sido praticado contra mulher (fato dito qualificante), examina-se se houve o contexto de violência doméstica.

O juízo de subsunção é passível de variação interpretativa, razão pela qual a análise é feita no âmbito da possibilidade. Logo, na primeira verificação há um juízo de certeza sobre a existência do fato dito qualificante, enquanto que na segunda ocorre um juízo de possibilidade acerca da subsunção do fato ao tipo legal da qualificadora.

Esse juízo subsuntivo, consistente na segunda verificação, pode ou não ser obrigatório independentemente da natureza objetiva ou subjetiva da qualificadora. As qualificadoras objetivas do fogo ou veneno, caso demonstradas num juízo de certeza, carecerão do juízo de subsunção, pois a lei já realizou um juízo de valor prévio presumindo de antemão a crueldade em tais meios.

Idêntica situação ocorre com algumas das qualificadoras subjetivas, pois comprovado que o crime decorreu de paga ou promessa de recompensa, a qualificadora deve ser admitida, pois a própria lei presume a torpeza. 
Revista Eletrônica de Direito Processual - REDP.

Rio de Janeiro. Ano 15. Volume 22. Número 2. Maio a Agosto de 2021

Periódico Quadrimestral da Pós-Graduação Stricto Sensu em Direito Processual da UERJ

Patrono: José Carlos Barbosa Moreira (in mem.). ISSN 1982-7636. pp. 268-301

www.redp.uerj.br

Em tais casos, seja qual for sua natureza, a qualificadora será admitida caso supere a primeira verificação, sem a necessidade do segundo procedimento.

Porém, quando houver equiparação analógica, ${ }^{40}$ seja a qualificadora objetiva ou subjetiva, não bastará a prova certa do fato dito qualificante e necessariamente obrigará o juízo de valor na fase subsequente para admissão ou não da qualificadora.

Nesses casos, a exigência do juízo de valor coloca a qualificadora numa zona cinzenta entre o inadmissível e o admissível. Nesse momento - e somente nele -, justificase a afirmação de que apenas a qualificadora manifestamente improcedente deve ser excluída da pronúncia.

O procedimento de dupla verificação das qualificadoras é aplicável no que couber às causas de aumento de pena situadas na parte especial e em leis especiais.

\section{Pronúncia e critérios de efetividade}

Segundo Vicente Greco Filho, a pronúncia é uma garantia de liberdade ao acusado e visa "evitar que alguém que não mereça ser condenado possa sê-lo em virtude do julgamento soberano, em decisão, quiçá, de vingança pessoal ou social." ${ }^{41}$

O julgamento pelo tribunal do júri é um ato complexo. Muito embora a decisão definitiva em regra seja atribuída aos jurados, isso não significa que o juiz togado seja inerte ou tenha função meramente burocrática, Atua, assim, também como juiz da causa, pois "o júri, como juiz natural dos crimes dolosos contra a vida, existe se e quando o juiz togado admite crime de sua competência em decisão". ${ }^{42}$

Não há qualquer ofensa à soberania dos veredictos pelo controle judicial prévio exercido no juízo da acusação, seja por não se tratar de princípio absoluto e

\footnotetext{
${ }^{40}$ Como ocorre a exemplo do art. $121, \S 2^{\circ}$, inc. I ("por outro motivo torpe"), inc. III ("outro meio insidioso ou cruel, ou de que possa resultar perigo comum") e inc. IV ("outro recurso que dificulte ou torne impossível a defesa do ofendido"), do Código Penal.

${ }^{41}$ GRECO FILHO, Vicente. Questões polêmicas sobre a pronúncia. In: TUCCI, Rogério Lauria (Coord.). Tribunal do júri. Estudo sobre a mais democrática instituição jurídica brasileira. São Paulo: Saraiva, 1999, p. 119.

42 VIDAL, Luís Fernando Camargo de Barros. Homicídio qualificado e procedimento do júri. Revista Brasileira de Ciências Criminais. São Paulo, v. 8, n. 32, out./dez., 2000, p. 104. Na mesma toada, Vicente Greco Filho assevera que o júri é o juiz natural, mas somente quando a garantia da liberdade esteja preservada pela triagem feita anteriormente pelo juiz na primeira fase (GRECO FILHO, Vicente. Questões polêmicas sobre a pronúncia. In: TUCCI, Rogério Lauria (Coord.). Tribunal do júri. Estudo sobre a mais democrática instituição jurídica brasileira. São Paulo: Saraiva, 1999, p. 120).
} 
Revista Eletrônica de Direito Processual - REDP.

Rio de Janeiro. Ano 15. Volume 22. Número 2. Maio a Agosto de 2021

Periódico Quadrimestral da Pós-Graduação Stricto Sensu em Direito Processual da UERJ

Patrono: José Carlos Barbosa Moreira (in mem.). ISSN 1982-7636. pp. 268-301

www.redp.uerj.br

que pode ser relativizado, ${ }^{43}$ seja por essa fase precedente ensejar uma limitação racional e legítima ao exercício do poder punitivo estatal.

O primeiro passo para assegurar a efetividade da pronúncia é compreender o significado e o alcance dos requisitos do art. 413 do Código de Processo Penal e, por consequência, rejeitar fórmulas vazias que nada esclarecem sobre os limites da admissibilidade da acusação e buscam reduzir a pronúncia a uma decisão apenas impulsionadora da marcha procedimental e sem relevância no plano da garantia.

Todavia, isso não é o bastante. As particularidades do tribunal do júri (soberania dos veredictos, íntima conviccção e o caráter leigo dos julgadores) demandam que o juízo de admissibilidade da acusação opere com real eficiência, não apenas na delimitação da matéria que será objeto de julgamento em plenário, mas também fornecendo condições adequadas para essa tarefa, isso visando reduzir o potencial de erro dos jurados.

Desta forma, é imprescindível agregar determinados parâmetros qualitativos aptos a conferir efetividade à pronúncia e que a permitam atuar genuinamente como uma garantia contra acusações temerárias. ${ }^{44}$

\footnotetext{
${ }^{43}$ Como exemplos, a apelação com fulcro no art. 593, inc. III, alínea "d", do Código de Processo Penal e a desconstituição de decisão condenatória do tribunal do júri por meio de revisão criminal.

${ }^{44}$ Existem fortes argumentos criticando o juízo de admissibilidade mais rigoroso da primeira fase do júri. Para Marcella Mascarenhas Nardelli, essa opção decorre da amplitude dada à intima convicção na fase de plenário a não permitir o adequado controle intersubjevo. Na carência de mecanismos que proporcionam um controle sobre o processo de formação de convencimento dos jurados, isto é, ao invés de zelar pela qualidade da informação (prova) que chega aos jurados, deu-se preferência pelo estabelecimento de um rigoroso critério de filtragem dos casos enviados ao júri, o que contribui para a irracionalidade das decisões proferidas pelos jurados. Nessa ótica, o sistema não confiaria na capacidade do juiz leigo em julgar e depositaria a expectativa de controle na fase judicial antecedente para evitar condenações injustas. Esse juízo mais rigoroso e profundo realizado na primeira fase, com instrução exaustiva, aproximaria-se de um juízo antecipado de culpa (NARDELLI, Marcella Mascarenhas. A prova no tribunal do júri. Uma abordagem racionalista. Rio de Janeiro: Lumen Juris, 2019, p. 412-413; 418-422). De fato, há certa hipertrofia no juízo da acusação, cujo espectro probatório é amplo e praticamente idêntico ao do procedimento ordinário. Essa característica resulta numa tendência de aproveitamento em plenário da prova pessoal anteriormente produzida na instrução preliminar. Assim, em detrimento da oralidade, as partes deixam de arrolar ou desistem de testemunhas que poderiam ser ouvidas perante os jurados. Existem propostas de sumarização da primeira fase do procedimento, como a realização do juízo de admissibilidade da acusação a partir dos elementos informativos constantes do inquérito policial, deixando a inquirição de testemunhas em juízo somente para hipóteses imprescindíveis a critério do juiz. Nesse sentido: GOULART, Fábio Rodrigues. Tribunal do júri. Aspectos críticos relacionados à prova. São Paulo: Atlas, 2008, p. 68; 133; TASSE, Adel El. Júri. Teoria e prática. Curitiba: Juruá, 2018, p. 161-170. Além de depender de alteração da lei, essa opção implicaria em modificar a lógica atual do procedimento do júri, flexibilizando a garantia de uma fase intermediária judicializada em prol da centralidade do juízo oral realizado em plenário. Assim, de lege lata, deve-se respeitar o procedimento estabelecido legalmente para o judicium accusationis e buscar condições para que atue com eficiência sem que isso acarrete desprestígio para a fase de plenário.
} 
Revista Eletrônica de Direito Processual - REDP.

Rio de Janeiro. Ano 15. Volume 22. Número 2. Maio a Agosto de 2021

Periódico Quadrimestral da Pós-Graduação Stricto Sensu em Direito Processual da UERJ

Patrono: José Carlos Barbosa Moreira (in mem.). ISSN 1982-7636. pp. 268-301

www.redp.uerj.br

Esses critérios de efetividade são: i) contraditório; ii) imediação judicial; iii) auxílio hermenêutico a partir da concepção dos standards de prova.

\subsection{Contraditório}

O art. 155 do Código de Processo Penal preconiza que o juiz formará seu convencimento pela livre apreciação da prova produzida em contraditório judicial, ressalvando-se as provas irrepetíveis, cautelares e antecipadas.

O dispositivo fixa como condição para a validade e valoração das provas a produção em contraditório de partes. Assim, a prova passível de livre valoração é aquela incorporada ao processo com a devida observância do procedimento previsto em lei, que exige como regra o contraditório contemporâneo na sua formação.

Ada Pellegrini Grinover destaca a presença das partes como condição de validade das provas pessoais, ou mais precisamente, na atividade dirigida à constituição do material probatório a ser usado pelo juiz na formação de seu convencimento, entendendo viciadas tanto a prova colhida sem a presença do juiz, como aquela tomada pelo juiz, mas sem a presença das partes. ${ }^{45}$

Por sua vez, o contraditório durante a formação da prova pessoal maximiza a dialética a partir da verificação e da refutação das teses apresentadas pelas partes.

Segundo Paolo Tonini, há inegável interesse que a causa seja julgada de acordo com o modo dialético, isto é, mediante atividade recíproca das partes e a partir do contraditório "para a prova", o que confere ao juiz melhor condição para valorar os elementos probatórios. $^{46}$

Discute-se a incidência do artigo 155 do Código de Processo Penal no juízo da acusação. Sob o fundamento de que na pronúncia não há análise de mérito e por não

\footnotetext{
45 GRINOVER, Ada Pellegrini. O conteúdo da garantia do contraditório. In: Novas tendências do direito processual: de acordo com a Constituição de 1988. Rio de Janeiro: Forense, 1990, p. 22-24.

46 TONINI, Paolo. A prova no processo penal italiano. Tradução de Alexandra Martins e Daniela Mróz. São Paulo: RT, 2002, p. 89. Em complemento, assevera Nereu José Giacomoli que "para condenar o réu, considera-se como prova o que foi produzido pelo contraditório do pólo defensivo, admitindo-se, para absolver, os elementos colhidos sem o contraditório defensivo" (GIACOMOLLI, Nereu José. Reformas (?) do processo penal. Considerações críticas. Rio de Janeiro: Lumen Juris, 2008, p. 22).
} 
Revista Eletrônica de Direito Processual - REDP.

Rio de Janeiro. Ano 15. Volume 22. Número 2. Maio a Agosto de 2021

Periódico Quadrimestral da Pós-Graduação Stricto Sensu em Direito Processual da UERJ

Patrono: José Carlos Barbosa Moreira (in mem.). ISSN 1982-7636. pp. 268-301

www.redp.uerj.br

constituir um juízo de certeza, cujo objetivo é apenas firmar a competência do tribunal do júri, parte da doutrina sustenta a resposta negativa. ${ }^{47}$

Não obstante, a imposição legal de mais uma etapa para verificação da admissibilidade da acusação, agora judicializada, antes do julgamento em plenário, teleologicamente força a incidência do art. 155 do Código de Processo Penal ao judicium accusationis, pois visa tornar a análise mais rigorosa ao reclamar elementos produzidos com a participação das partes.

A justificativa de que se trata de um mero juízo de admissibilidade não é suficiente para afastar o contraditório da primeira fase do rito do júri, sob pena de indevida equiparação com o recebimento da denúncia. Ora, admitindo-se a pronúncia exclusivamente com base em elementos informativos, além da perda de tempo em se produzir a prova judicializada, não haveria diferença com o exame realizado na peça inicial acusatória.

O contraditório como condição para a valoração dos elementos que embasam a pronúncia tem como efeito a filtragem indireta do material que será avaliado pelos jurados, ou seja, somente a questão controversa que foi objeto de prova judicial pode ser enviada ao plenário. Evita-se, ainda que reflexamente, uma futura condenação fundada unicamente em elementos informativos. ${ }^{48}$

É incoerente considerar insuficientes os elementos informativos para um juízo de certeza e, de outro lado, admitir que possam servir exclusivamente para a pronúncia. Se não tem aptidão para ensejar eventual condenação, não se justifica que sejam valorados

\footnotetext{
${ }^{47}$ Nesse sentido: BONFIM, Edilson Mougenot. Júri. Do Inquérito ao plenário. 4. ed. São Paulo: Saraiva, 2012, p. 168; ANTUNES, Rodrigo Merli. Comentários ao item 29. In: CANO, Leandro Jorge Bittencourt; ANTUNES, Rodrigo Merli; DOMINGUES, Alexandre de Sá. O tribunal do júri na visão do juiz, do promotor e do advogado. Questões práticas fundamentais. Versão compacta. São Paulo: Atlas, 2014, p. 85; CORRÊA, Luciana Perpétua. Procedimento especial do júri - não aplicação do artigo 155 do Código de Processo Penal - Possibilidade da decisão de pronúncia embasar-se em provas produzidas em fase inquisitorial. De Jure. Revista Jurídica do Ministério Público do Estado de Minas Gerais, Belo Horizonte, v. 11, n. 18, jan./jun. 2012. p. 211-212. Sob a égide da Constituição de 1946, José Frederico Marques referia que "O contraditório é essencial à defesa na fase do judicium causae, e não na fase do judicium accusationis ou instrução". No entanto, o autor admitia o contraditório na instrução preliminar por força da literalidade da segunda parte do art. 141, § 25, da Carta de 1946, que dispunha genericamente que "A instrução criminal será contraditória” (MARQUES, José Frederico. A instituição do júri. São Paulo: Saraiva, 1963, p. 218, destaque do original).

48 OLIVEIRA, Vitor Eduardo Tavares de. A impossibilidade de pronúncia com base nos elementos de informação do inquérito. In: PASSADORE, Bruno de Almeida; COSTA, Renata Tavares da; OLIVEIRA, Vitor Eduardo Tavares de (coord.). O tribunal do júri e a Defensoria Pública. Florianópolis: Tirant lo Blanch, 2018, p. 115.
} 
Revista Eletrônica de Direito Processual - REDP.

Rio de Janeiro. Ano 15. Volume 22. Número 2. Maio a Agosto de 2021

Periódico Quadrimestral da Pós-Graduação Stricto Sensu em Direito Processual da UERJ

Patrono: José Carlos Barbosa Moreira (in mem.). ISSN 1982-7636. pp. 268-301

www.redp.uerj.br

para o juízo de admissibilidade da acusação e assim legitimar a etapa de plenário, onde justamente ocorrerá o juízo de certeza sobre a totalidade da causa. ${ }^{49}$

Antevendo-se a existência isolada de elementos informativos, inábeis por si só para ensejar eventual condenação, não há razão para a admissão da acusação para julgamento em plenário pela via da pronúncia.

$O$ fato de testemunhas eventualmente ausentes na instrução preliminar comparecerem em plenário em data futura não legitima o uso exclusivo de elementos informativos para a pronúncia. A judicialização do exame de admissibilidade constitui um meio legítimo de contenção do poder punitivo estatal, independentemente da repetibilidade da prova em plenário.

O emprego de elementos que não passaram pelo crivo do contraditório contemporâneo somente se justifica em se tratando de prova não repetível, cautelar ou antecipada, ou ainda de prova pré-constituída produzida antes ou fora do processo, cujo contraditório ocorre de forma diferida. Para a prova constituenda, isto é, aquela que deve ser constituída no processo, exige-se o contraditório contemporâneo em sua formação.

No mais, é equivocado o argumento que autoriza o uso de elementos informativos em caráter exclusivo por não haver julgamento definitivo de mérito na pronúncia.

$\mathrm{Na}$ verdade, há análise do mérito, pois a materialidade é avaliada de forma equiparada a uma sentença definitiva, ou seja, mediante um juízo de certeza. Ainda que a decisão sobre a materialidade não seja definitiva e possa sofrer alteração em plenário, essa provisoriedade não afeta o exame do mérito, que de fato ocorre na pronúncia ${ }^{50}$

No que toca à autoria, embora se trate de um juízo de probabilidade, o mérito é igualmente avaliado haja vista a autoria caracterizar matéria de fundo. ${ }^{51}$

\footnotetext{
${ }^{49}$ Por certo, a adoção isolada deste critério não basta para evitar condenações embasadas exclusivamente em elementos informativos. Outros mecanismos de controle devem operar em plenário para evitar essa situação que, de todo modo, é potencialmente reduzida caso a pronúncia seja proferida com base em elementos produzidos em contraditório de partes.

${ }^{50}$ Segundo Luis Fernando Camargo de Barros Vidal, é incorreto a afirmar que o juiz não analisa o mérito, pois "Se para a pronúncia deve o juiz proclamar a existência de um crime, ele examina o mérito da acusação" (VIDAL, Luís Fernando Camargo de Barros. Homicídio qualificado e procedimento do júri. Revista Brasileira de Ciências Criminais. São Paulo, v. 8, n. 32, out./dez., 2000, p. 103).

${ }^{51}$ Para Rafael Fecury, a decisão de pronúncia analisa o mérito, mas não o julga (NOGUEIRA, Rafael Fecury. A decisão de pronúncia no processo penal brasileiro: valoração da prova e limites à motivação. Rio de Janeiro: Lumen Juris, 2018, p. 75).
} 
Revista Eletrônica de Direito Processual - REDP.

Rio de Janeiro. Ano 15. Volume 22. Número 2. Maio a Agosto de 2021

Periódico Quadrimestral da Pós-Graduação Stricto Sensu em Direito Processual da UERJ

Patrono: José Carlos Barbosa Moreira (in mem.). ISSN 1982-7636. pp. 268-301

www.redp.uerj.br

Talvez uma das razões para o afastamento do art. 155 da pronúncia seja a equivocidade da expressão "indícios". ${ }^{52}$ Como lembra Antonio Magalhães Gomes Filho, não raro afirma-se que os elementos informativos "não são provas, mas simples indícios, e, com isso, admite-se o seu ingresso no processo com o que fatalmente acabarão por ser valorados pelo juiz ou, pior, pelos jurados, que decidem sem motivar". 53

Sendo os indícios uma prova "mais tênue" e sem eficácia persuasiva ampla para um juízo de certeza completo sobre o mérito, facilita-se a sua equiparação aos elementos informativos. Mas essa equivalência é indevida, pois elementos de informação e elementos de prova tem funções diferentes no processo pelo modo como são produzidos.

Assim, para os fins do art. 413 do Código de Processo Penal, indícios, como prova "mais leve" e apta a alcançar um juízo de probabilidade, mas não necessariamente para se obter a certeza, deve ser necessariamente obtido a partir da prova judicializada. ${ }^{54}$

Em resumo, os seguintes argumentos corroboram a aplicação do art. 155 do Código de Processo Penal para a pronúncia: i) hermeneuticamente, o texto legal não faz distinção sobre a incidência no procedimento comum ou em especiais; ii) topograficamente, o preceito consta no Título VII ("Da Prova"), contido no Livro I ("Do Processo em Geral”) e não no Livro II (“Dos Processos em Espécie”), sendo aplicável, portanto, para todos os procedimentos; iii) teleologicamente, não há sentido em estabelecer uma fase judicial para admissibilidade da acusação e depois autorizar a decisão apenas com base em elementos informativos, pois onde houver elementos de informação (produzidos unilateralmente) e de prova (produzidos em contraditório), há que se diferenciar a função desses elementos durante a persecução penal; iv) sistemicamente, representaria a indevida equivalência com o juízo de admissibilidade realizado no recebimento da denúncia, esse sim necessariamente fundado em elementos informativos e destinados ao exame da justa causa da ação penal e de medidas cautelares em geral.

\footnotetext{
${ }^{52} \mathrm{Cf}$. item 3.1, supra, sobre o duplo sentido da expressão indícios, seja como prova mais tênue ou leve, seja prova indireta.

${ }_{53}$ GOMES FILHO, Antonio Magalhães. A motivação das decisões penais. São Paulo: Revista dos Tribunais, 2013, p. 138.

${ }^{54}$ Entendendo que somente os elementos que passaram pelo contraditório podem fundamentar a pronúncia: TORRES, José Henrique Rodrigues. O júri garantista. Boletim IBCCRIM. São Paulo, n. 226, v. 19, setembro de 2011, p. 08; ZVEIBIL, Daniel Guimarães. O arbítrio palavreado no processo penal: breve ensaio sobre a pronúncia e o "in dubio pro societate". Revista Brasileira de Ciências Criminais. São Paulo, v. 16, n. 74, set./out. 2008, p. 290; 292; NASSIF, Aramis. O novo júri brasileiro. Porto Alegre: Livraria do Advogado, 2009, p. 59.
} 
Revista Eletrônica de Direito Processual - REDP.

Rio de Janeiro. Ano 15. Volume 22. Número 2. Maio a Agosto de 2021

Periódico Quadrimestral da Pós-Graduação Stricto Sensu em Direito Processual da UERJ

Patrono: José Carlos Barbosa Moreira (in mem.). ISSN 1982-7636. pp. 268-301

www.redp.uerj.br

Pode-se dizer, ainda, que o advento do instituto do juiz das garantias pela Lei 13.964/19 trouxe um argumento de reforço ao contraditório na pronúncia. A despeito de estabelecer a segmentação da atividade jurisdicional, estabelecendo órgãos judiciais diversos e com funções específicas para cada fase (juiz das garantias e juiz da instrução e julgamento), o art. $3^{\circ}-\mathrm{C}, \S 3^{\circ}$, do Código de Processo Penal impôs a exclusão físico-digital do inquérito policial em relação ao expediente que formará os autos judiciais.

Ainda que mais visível no juízo da causa pela intuitiva distinção entre juiz togado e jurados, o instituto do juiz das garantias se aplica igualmente ao juízo da acusação, pois havendo instrução judicial e contraditória para a admissibilidade da acusação, o juiz da instrução preliminar se equipara ao juiz da instrução e julgamento.

Justifica-se, assim, a existência de órgão judicial específico para a fase de investigação criminal, evitando que o juiz da instrução preliminar tenha acesso aos elementos informativos ou que profira decisões que envolvam a potencial formação de préjuízos capazes de afetar a imparcialidade da análise sobre a admissibilidade da acusação.

\subsection{Imediação}

Como visto, o art. 155 do Código de Processo Penal demanda "contraditório judicial” para a prova, pressupondo não só a participação das partes, mas também do juiz.

Segundo Cabezudo Rodríguez, a imediação se caracteriza pelo contado direto e "livre de interferências e em unidade espaço-temporal com todos os atos fática e juridicamente relevantes para a configuração do objeto do processo, compreendendo tanto a atividade alegatória como a probatória que se desenvolve no processo". ${ }^{55}$

$\mathrm{Na}$ atividade probatória, a imediação se manifesta impondo que o juiz assista e participe da produção de provas pessoais em juízo, ou seja, tomando contato direto com testemunhas, informantes, peritos e acusados, viabilizando a percepção direta das informações prestadas e sua aderência à realidade, além da sinceridade do depoente.

Por essas características, a imediação se qualifica duplamente: a) como técnica que atua para formar provas pessoais, sendo um fator determinante, ainda que não o único, para

\footnotetext{
${ }^{55}$ RODRÍGUEZ, Nicolás Cabezudo. Del principio de inmediación, sus excepciones y los instrumentos tecnológicos. Valencia: Tirant lo Blanch, 2010, p. 21, tradução livre.
} 
Revista Eletrônica de Direito Processual - REDP.

Rio de Janeiro. Ano 15. Volume 22. Número 2. Maio a Agosto de 2021

Periódico Quadrimestral da Pós-Graduação Stricto Sensu em Direito Processual da UERJ

Patrono: José Carlos Barbosa Moreira (in mem.). ISSN 1982-7636. pp. 268-301

www.redp.uerj.br

que os elementos de convicção alcancem o status de prova; b) como método de conhecimento judicial, isto é, de captação da realidade que alimenta o convencimento do juiz ou tribunal, prática que inclui a presença física do juiz e também a interação com os elementos de convicção, conferindo maior idoneidade para o juízo de valoração exercido pelo juiz na comparação entre as alegações das partes e o quanto produzido pela prova. ${ }^{56}$

A imediação pode ser compreendida em dois sentidos. Em sentido amplo diz respeito à presença do juiz ao ato, equiparando-se à judicialidade. Tem como propósito aportar confiança de que serão observados os direitos e garantias processuais. ${ }^{57}$

De outro lado, a imediação em sentido estrito abrange não só a presença judicial, mas exige que o juiz que recebeu os atos de prova seja o mesmo a emitir a sentença, materializando a identidade física do juiz. A ausência de intermediários que possam distorcer, voluntária ou involuntariamente, a informação transmitida confere ao julgador que participou do ato de prova uma posição superior para valorar os elementos probatórios. $^{58}$

A identidade física é a principal referência da oralidade no processo e seu elemento transcendental. Adotada a premissa de que o contato direto do juiz com as fontes de prova é um fator importante para a valoração do conjunto probatório e com potencial de contribuir para uma decisão mais acertada no plano fático, pouco adiantará a prova pessoal ser colhida oralmente e na presença de um juiz, se esse magistrado não for o responsável por examinar o resultado da atividade probatória ali realizada e a proferir a respectiva sentença, pois não fruirá das vantagens da imediação no momento decisório.

A identidade física do juiz é relevante não apenas em julgamentos definitivos, mas também em juízos de admissibilidade da acusação, pois se somente os elementos de prova podem conduzir à pronúncia, faz-se necessário que o juiz que atuou na instrução preliminar valore as provas de cuja produção participou e emita a decisão subsequente.

\footnotetext{
${ }^{56}$ RODRÍGUEZ, Nicolás Cabezudo. Del principio de inmediación, sus excepciones y los instrumentos tecnológicos. Valencia: Tirant lo Blanch, 2010, p. 90-92.

57 ABIÂN, Rosario Herrera. La inmediación como garantía procesal (en el proceso civil y en el proceso penal). Granada: Editorial Comares, 2006, p. 04.

${ }_{58}$ ABIÁN, Rosario Herrera. La inmediación como garantía procesal (en el proceso civil y en el proceso penal). Granada: Editorial Comares, 2006, p. 04-05. Sobre os demais sentidos da imediação, cf. GOMES, Décio Alonso. Prova e imediação no processo penal. Salvador: Juspodivm, 2016.
} 
Revista Eletrônica de Direito Processual - REDP.

Rio de Janeiro. Ano 15. Volume 22. Número 2. Maio a Agosto de 2021

Periódico Quadrimestral da Pós-Graduação Stricto Sensu em Direito Processual da UERJ

Patrono: José Carlos Barbosa Moreira (in mem.). ISSN 1982-7636. pp. 268-301

www.redp.uerj.br

Quanto ao direito processual vigente, dispõe o art. 399, § $2^{\circ}$, do Código de Processo Penal que "O juiz que presidiu a instrução deverá proferir a sentença". 59 Numa interpretação literal, ao referir "sentença", o dispositivo aparentemente exclui as decisões interlocutórias de pronúncia e desclassificação, pois são decisões interlocutórias, enquanto a absolvição sumária e a impronúncia, por serem sentenças, estariam sujeitas à vinculação.

A interpretação restrtitiva não merece prosperar. Quando os autos são encaminhados ao juiz para proferir a decisão final do juízo da acusação, não há como avaliar antecipadamente que espécie de decisão será proferida (sentença ou decisão interlocutória).

Desta forma, não tem cabimento instituir tratamento diferenciado no bojo do mesmo procedimento, isto é, estipular a vinculação ou não em razão da natureza da decisão a ser proferida, que só será conhecida após sua emissão. ${ }^{60}$

Ademais, assim como as outras decisões do juízo da acusação, a pronúncia tem os mesmos requisitos formais de uma sentença (relatório, fundamentação e dispositivo), “o que demonstra a necessidade de seu prolator ser o mesmo profissional que colheu a instrução nos moldes do que dispõe a lei em comento, afinal, tais decisões são, formalmente, sentenças." 61

A ampla produção de provas na instrução preliminar, notadamente as provas pessoais, permite concluir que está presente no juízo da acusação a mesma ratio justificadora da identidade física no procedimento comum.

\subsection{Standard de prova}

Na redação dada pela Lei 11.689/08, o art. 413 do Código de Processo Penal passou a exigir indícios "suficientes" de autoria, remetendo à ideia de níveis de probabilidade.

\footnotetext{
${ }^{59}$ Sobre o sentido e alcance do art. 399, $\S 2^{\circ}$, do Còdigo de Processo Penal, cf. BADARÓ, Gustavo Henrique Righi Ivahy. Juiz natural no processo penal. São Paulo: Revista dos Tribunais, 2014, p. 640.

${ }^{60}$ Esse potencial de variabilidade levou Magalhães Noronha a atribuir natureza jurídica de sentença à decisão de pronúncia, concluindo que "tanto é sentença que o juiz pode absolver o acusado" (NORONHA, Edgard Magalhães. Curso de direito processual penal. 16. ed. São Paulo: Saraiva, 1984, p. 247-248).

${ }^{61}$ CAMPOS, Walfredo Cunha. Tribunal do júri. Teoria e prática. 3. ed. São Paulo: Atlas, 2014, p. 82, destaque do original. No mesmo sentido, para Hermínio Marques Porto a decisão de pronúncia é exteriorizada na forma de sentença e tem estrutura semelhante (PORTO, Hermínio Alberto Marques. Júri. Procedimento e aspectos do julgamento. 12. ed. São Paulo: Saraiva, 2007, p. 70).
} 
Revista Eletrônica de Direito Processual - REDP.

Rio de Janeiro. Ano 15. Volume 22. Número 2. Maio a Agosto de 2021

Periódico Quadrimestral da Pós-Graduação Stricto Sensu em Direito Processual da UERJ

Patrono: José Carlos Barbosa Moreira (in mem.). ISSN 1982-7636. pp. 268-301

www.redp.uerj.br

$\mathrm{Na}$ verdade, a Lei 11.689/08 apenas consolidou o entendimento então prevalente na doutrina à época. Apesar de não constar o adjetivo "suficiente" no art. 408 da redação revogada do Código de Processo Penal, Borges da Rosa entendia que para a pronúncia os indícios não podiam ser "fracos", mas sim "veementes" ou "suficientes". 62

Eduardo Espínola Filho também manifestava orientação semelhante com base na interpretação a contrario sensu do revogado art. 409 do Código de Processo penal, pois inexistindo "indício suficiente de que seja o réu o seu autor", a impronúncia teria lugar. Logo, para a pronúncia, os indícios deveriam ser "suficientes". 63

Como se percebe, a noção de graus de probabilidade já era latente na legislação processual antes da Reforma de 2008. ${ }^{64}$ Nesse ponto, para melhor compreensão e auferir objetividade aos juízos de probabilidade enunciados na lei, é interessante investigar a idéia dos standards de prova ou modelos de constatação.

Apesar de não se submeter a nenhuma norma predeterminada, a livre valoração da prova se sujeita às regras de lógica de modo a tornar a análise mais objetiva. Dentre os enfoques que buscam tornar o livre convencimento passível de um controle racional estão os standards de prova ou modelos de constatação, que funcionam como critérios pelos quais o juízo de fato é realizado. ${ }^{65}$

Os standards dizem respeito a níveis de suficiência probatória exigidos para reputar como processualmente verdadeira uma determinada hipótese fática.

$\mathrm{Na}$ verdade, consubstanciam-se em juízos de probabilidade de graus diferentes, mais ou menos rigorosos conforme o caso, até porque a atividade jurisdicional, ainda que tenha como fim alcançar um juízo de certeza, sempre atuará no campo da probabilidade, seja pela falibilidade humana em si mesma, seja pela existência de limites legais e constitucionais à atividade probatória das partes.

\footnotetext{
${ }^{62}$ ROSA, Borges da. Comentários ao Código de Processo Penal. Atualizado por Angelito A. Aiquel. 3. ed. São Paulo: Revista dos Tribunais, 1982, p. 506.

${ }^{63}$ ESPÍNOLA FILHO, Eduardo. Código de Processo Penal brasileiro anotado. v. IV. 5. ed. Rio de Janeiro: Editora Rio, 1976, p. 249.

${ }^{64}$ A idéia de gradação está presente também em outros dispositivos, como o art. 126 ("existência de indícios veementes da proveniência ilícita dos bens"), art. 134 ("desde que haja certeza da infração e indícios suficientes da autoria") e art. 312 ("quando houver prova da existência do crime e indício suficiente de autoria"), todos do Código de Processo Penal.

${ }^{65}$ KNIJNIK, Danilo. A prova nos juízos cível, penal e tributário. Rio de Janeiro: Forense, 2007, p. 16-18.
} 
Revista Eletrônica de Direito Processual - REDP.

Rio de Janeiro. Ano 15. Volume 22. Número 2. Maio a Agosto de 2021

Periódico Quadrimestral da Pós-Graduação Stricto Sensu em Direito Processual da UERJ

Patrono: José Carlos Barbosa Moreira (in mem.). ISSN 1982-7636. pp. 268-301

www.redp.uerj.br

De forma geral, três standards de prova podem ser enunciados: ${ }^{66}$ i) preponderância de prova, aplicável ao processo civil, onde o julgamento deve ser emitido em favor daquele favorecido pela preponderância de provas, sendo considerado provado o que é "mais provável do que não"; ii) prova clara e convincente, aplicável ao processo civil, mas em casos excepcionais, cujos valores transcendem à esfera meramente patrimonial, como assuntos de família (perda do poder familiar etc.) ou improbidade administrativa, que demanda alta probabilidade e é superior ao da preponderância de prova; iii) prova acima da dúvida razoável, ${ }^{67}$ aplicável ao processo penal, normalmente espelhado nos ordenamentos da civil law pela presunção de inocência, muito embora haja controvérsia sobre o que consiste a "dúvida razoável", entende-se que há exigência de prova acima da "alta probabilidade".

Não se trata de definir numérica e quantitativamente como o juízo de fato ocorrerá, o que seria irrealizável, mas um critério que pode ensejar um controle da racionalidade das decisões considerando as premissas adotadas e as conclusões obtidas na decisão judicial. Entre a análise matemática das provas e o exame com base na mera intuição subjetiva ou crença interna, insere-se um critério que pode ser formado racionalmente e submetido a contraditório. $^{68}$

Os standards de prova não estão livres de subjetivismo, pois não há modelo de constatação totalmente isento nesse sentido. Na verdade, agregado aos standards de prova,

\footnotetext{
${ }^{66}$ KNIJNIK, Danilo. A prova nos juízos cível, penal e tributário. Rio de Janeiro: Forense, 2007, p. 37-44. $\mathrm{O}$ autor faz referência ainda a um quarto tipo de modelo de constatação, a saber, quando o juiz se vale de prova indireta (indiciária). Nesse caso, considerando a maior chance de erro da prova indireta (não pela sua inferioridade com a prova direta, já que inexistente, mas pela potencialidade de erro), "o modelo de constatação 'deveria excluir qualquer hipótese razoável que não a de culpa"'. Trata-se de um standard mais rigoroso do que o da prova acima da dúvida razoável (p. 42, destaque do original). Pode-se agregar ainda outro standard, no caso, a probable cause (causa provável) que, para Danilo Knijnik, "é extremamente rarefeito, se comparado à preponderância ou à prova acima da dúvida razoável", ou seja, trata-se de um modelo de constatação de tipo fraco (p. 89; 91, destaque do original). No Brasil, equivaleria, mutatis mutandis, aos requisitos para a decretação de medidas cautelares penais, notadamente a busca e apreensão.

${ }^{67}$ Apesar da aparente semelhança, o standard de prova "acima da dúvida razoável" não se confunde com o princípio da presunção de inocência. Como regra de julgamento, a dúvida sobre qualquer fato penalmente relevante se resolve em favor do acusado, mas não explica que espécie de standard de prova deve ser usado para solucionar a dúvida remanescente (mais ou menos rigoroso). Não obstante, a prova acima da dúvida razoável é o único standard compatível com as particularidades do processo penal. Segundo Gustavo Badaró, "Todavia, embora a presunção de inocência não implique, em si, a adoção do standard de prova 'além da dúvida razoável', ela exige que o modelo de constatação adotado no processo penal represente o mais elevado nível de confirmação probatória que seja racionalmente exigível, para que a proposição seja considerada provada, isto é, verdadeira." (BADARÓ, Gustavo Henrique Righi Ivahy. Epistemologia judiciária e prova penal. São Paulo: Revista dos Tribunais, 2019, p. 247, destaque do original).

${ }^{68}$ KNIJNIK, Danilo. A prova nos juízos cível, penal e tributário. Rio de Janeiro: Forense, 2007, p. 37.
} 
Revista Eletrônica de Direito Processual - REDP.

Rio de Janeiro. Ano 15. Volume 22. Número 2. Maio a Agosto de 2021

Periódico Quadrimestral da Pós-Graduação Stricto Sensu em Direito Processual da UERJ

Patrono: José Carlos Barbosa Moreira (in mem.). ISSN 1982-7636. pp. 268-301

www.redp.uerj.br

a motivação da decisão judicial é o verdadeiro mecanismo de controle da racionalidade lógica do juízo fático realizado. ${ }^{69}$

Há dificuldade quanto à delimitação do conteúdo desses modelos de constatação, até mesmo como expressar, pela linguagem, o quantum de prova exigido para cada um desses graus. No entanto, a ausência de um quantitativo numérico ou matemático não retira o valor da construção, que contribui para o balizamento racional do resultado da valoração das provas. ${ }^{70}$

A ideia dos standards de prova se relaciona com a distribuição de erros entre as partes. Ao adotar um standard mais rigoroso no processo penal, como a prova acima da dúvida razoável, entre dois erros possíveis, isto é, uma condenação incorreta ou uma absolvição indevida, ao se exigir um quantum de prova maior para eventual condenação opta-se pela segunda hipótese.

Nesse sistema, é mais tolerável - e também mais provável que ocorra - o erro decorrente de uma absolvição indevida do que uma condenação equivocada.

A aplicação de standards ou modelos de constatação não se confunde com a atividade de valoração da prova. Primeiro é feita a análise valorativa da prova e alcança-se um resultado. Em seguida, esse resultado é confrontado com o standard adotado pela lei. ${ }^{71}$

Os standards de prova são percebidos mais facilmente quando comparadas as decisões finais de mérito do processo penal e do processo civil, cujos bens jurídicos possuem relevâncias diversas e por isso ensejam diferentes modelos de constatação, mais ou menos rigorosos conforme o caso.

Apesar disso, não se restringem aos juízos de fato definitivos e podem ser utilizados para o controle de outros provimentos judiciais emitidos ao longo da persecução penal.

\footnotetext{
${ }^{69}$ PALMA, Andrea Galhardo. Breve análise comparativa dos modelos de valoração e constatação da prova penal - standards probatórios - no Brasil, nos EUA e na Itália: crítica à regra beyond any reasonable doubt ou oltre ragionevole dubbio (além da dúvida razoável). In: ONODERA, Marcus Vinicius Kiyoshi; FILIPPO, Thiago Baldani Gomes De (coord.). Brasil e EUA: temas de direito comparado. São Paulo: Escola Paulista da Magistratura, 2017, p. 320.

${ }^{70}$ KNIJNIK, Danilo. A prova nos juízos cível, penal e tributário. Rio de Janeiro: Forense, 2007, p. 43-44.

${ }^{71}$ Como explica Gustavo Badaró, "Enquanto que a atividade de valoração da prova é regida por critérios epistemológicos, a definição do modelo de constatação ou do standard probatório para considerar que um enunciado fático está provado, é fruto de uma escolha axiológica." Assim, uma vez definido o método de valoração e obtendo a conclusão da hipótese fática que mais encontra suporte nas provas, "é preciso definir qual o nível que esse suporte probatório deve atingir, para que tal hipótese seja, racionalmente, considerada verdadeira." (BADARÓ, Gustavo Henrique Righi Ivahy. Editorial dossiê "Prova penal: fundamentos epistemológicos e jurídicos". Revista Brasileira de Direito Processual Penal. Porto Alegre, vol. 4, n. 1, jan./abr. 2018, p. 70. https://doi.org/10.22197/rbdpp.v4i1.138).
} 
Revista Eletrônica de Direito Processual - REDP.

Rio de Janeiro. Ano 15. Volume 22. Número 2. Maio a Agosto de 2021

Periódico Quadrimestral da Pós-Graduação Stricto Sensu em Direito Processual da UERJ

Patrono: José Carlos Barbosa Moreira (in mem.). ISSN 1982-7636. pp. 268-301

www.redp.uerj.br

Como lembra Danilo Knijnik, os standards se colocam como uma questão de direito antecedente e presumem prévio conhecimento das partes anteriormente ao julgamento da questão, permitindo o exercício do contraditório. ${ }^{72}$

Não é admissível, assim, a imposição inesperada e unilateral pelo juiz de standards casuísticos para as decisões proferidas ao longo da persecução penal, sob pena de inaceitável insegurança jurídica.

Apesar da ausência de regramento legal específico no direito brasileiro, a construção teórica dos standards de prova serve como paradigma hermenêutico visando auxiliar a definição do nível de prova quando a lei se vale de juízos de probabilidade, como ocorre nas medidas cautelares e pronúncia.

No caso específico da pronúncia, a gradação de probabilidade exigida na pronúncia é mais intensa na medida em que a lei processual impõe que sejam "suficientes".

Portanto, em comparação com o recebimento da denúncia, os indícios de autoria que justificam a pronúncia devem ser mais robustos, pois do contrário não se justificaria o rito bifásico do júri. ${ }^{73}$

Nesse ponto se insere a relevância da contribuição da teoria dos standards de prova, pois facilitam a compreensão dos níveis distintos de probabilidade demandados pela lei brasileira para determinadas decisões, dentre as quais a pronúncia.

Para Rafael Fecury Nogueira, o standard para recebimento da denúncia quanto à autoria equivale à preponderância de prova, ou seja, o critério do "mais provável que não",

\footnotetext{
${ }^{72}$ KNIJNIK, Danilo. A prova nos juízos cível, penal e tributário. Rio de Janeiro: Forense, 2007, p. 33. No mesmo sentido. Andreia Galhardo Palma aponta que o juiz deve enunciar previamente o standard que será usado para viabilizar o controle da decisão e do raciocínio empregado (PALMA, Andrea Galhardo. Breve análise comparativa dos modelos de valoração e constatação da prova penal - standards probatórios - no Brasil, nos EUA e na Itália: crítica à regra beyond any reasonable doubt ou oltre ragionevole dubbio (além da dúvida razoável). In: ONODERA, Marcus Vinicius Kiyoshi; FILIPPO, Thiago Baldani Gomes De (coord.). Brasil e EUA: temas de direito comparado. São Paulo: Escola Paulista da Magistratura, 2017, p. 295).

${ }^{73}$ Nesse sentido: MARQUES, Jader. Tribunal do júri. Considerações críticas à Lei 11.689/08. Porto Alegre: Livraria do Advogado, 2009, p. 65. Semelhantemente, Nereu José Giacomolli assevera que "A carga de positividade desta decisão interlocutória há de ser maior daquela exigível ao recebimento da denúncia." (GIACOMOLLI, Nereu José. Reformas (?) do processo penal. Considerações críticas. Rio de Janeiro: Lumen Juris, 2008, p. 90). Da mesma forma, João Daniel Rassi e Maria Elizabeth Queijo ponderam que deve ser verificado "se houve robustecimento da prova indiciária durante a instrução preliminar" (QUEIJO, Maria Elizabeth; RASSI, João Daniel. Questões polêmicas atinentes ao novo procedimento do Tribunal do Júri. In: MARZAGÃO JÚNIOR, Laerte I. (coord.). Homicídio crime rei. São Paulo: Quartier Latin, 2009, p. 190).
} 
Revista Eletrônica de Direito Processual - REDP.

Rio de Janeiro. Ano 15. Volume 22. Número 2. Maio a Agosto de 2021

Periódico Quadrimestral da Pós-Graduação Stricto Sensu em Direito Processual da UERJ

Patrono: José Carlos Barbosa Moreira (in mem.). ISSN 1982-7636. pp. 268-301

www.redp.uerj.br

pois as duas hipóteses fáticas estão no mesmo plano de igualdade e a distribuição de erros nessa fase ocorre em desfavor do acusado. ${ }^{74}$

Já em relação à pronúncia, por refletir a confirmação da admissibilidade da acusação com base em material probatório coletado em juízo, o standard a ser adotado é o da prova clara e convincente. ${ }^{75}$

$\mathrm{Na}$ verdade, independentemente de um standard próprio fixado em lei ou sedimentado na jurisprudência pátria, importa reconhecer que, de lege lata, o juízo avançado de admissibilidade da acusação realizado na pronúncia possui exigência quantitativa de prova superior ao do recebimento da denúncia e da decretação de medidas cautelares penais em geral, demandando elevada probabilidade quanto à autoria.

\section{Pronúncia e o in dubio pro societate}

Diversos argumentos podem vulnerar a filtragem processual que deve ser realizada pela pronúncia, como a necessidade de comedimento na linguagem como forma de contornar a motivação necessária, a suposta ausência de análise de mérito ou por se tratar "mera" fase de admissibilidade da acusação. Como já se apontou acima, esses argumentos improcedem. ${ }^{76}$

Entretanto, a fragilização mais gravosa decorre do in dubio pro societate. Esse brocardo reflete uma tentativa incorreta de explicar o exame de admissibilidade da pronúncia a partir da interpretação inversa do que seria um juízo de probabilidade, resultando em uma fórmula meramente retórica e com grande potencial vulnerante da função de garantia da pronúncia.

\footnotetext{
${ }^{74}$ NOGUEIRA, Rafael Fecury. A decisão de pronúncia no processo penal brasileiro: valoração da prova e limites à motivação. Rio de Janeiro: Lumen Juris, 2018, p. 177. Para o autor, o próprio fato de não haver análise de provas, mas de elementos de informação, prejudica a adoção de um standard mais elevado para o recebimento da denúncia (p. 178).

${ }^{75}$ NOGUEIRA, Rafael Fecury. A decisão de pronúncia no processo penal brasileiro: valoração da prova e limites à motivação. Rio de Janeiro: Lumen Juris, 2018, p. 182.

${ }^{76}$ Cf. item 4.1, supra.
} 
Revista Eletrônica de Direito Processual - REDP.

Rio de Janeiro. Ano 15. Volume 22. Número 2. Maio a Agosto de 2021

Periódico Quadrimestral da Pós-Graduação Stricto Sensu em Direito Processual da UERJ

Patrono: José Carlos Barbosa Moreira (in mem.). ISSN 1982-7636. pp. 268-301

www.redp.uerj.br

Apesar de não possuir base normativa, parte da doutrina reconhece a validade do in dubio pro societate. Em regra, a justificativa gravita em prol da preservação da competência constitucional do tribunal do júri para análise em caso de dúvida. ${ }^{77}$

O fundamento, contudo, é pouco convincente e mascara uma realidade incontornável. O tribunal do júri é o juiz natural dos crimes dolosos contra a vida, mas desde que realizado o necessário - e efetivo - juízo de admissibilidade da acusação imposto pela legislação processual.

O in dubio pro societate não constitui uma fórmula mágica que, a pretexto de resguardar a competência do tribunal do júri, torna irrelevante e inoperante o judicium accusationis, reduzindo-o a mera etapa burocrática.

A alegação de que o júri, por ser uma garantia fundamental do réu, é melhor que o conselho de sentença decida é falaciosa, pois a lógica é justamente contrária. Para evitar decisões infundadas diante das particularidades do julgamento pelo tribunal do júri, a lei prevê rito bifásico e estabelece maior rigor na admissibilidade da acusação.

Segundo Hermínio Marques Porto, o exame das provas na pronúncia "não comporta soluções que mostrem preocupação dominante com a competência constitucional do Tribunal do Júri”. Isso porque a fase de admissibilidade da acusação tem sua razão de existir e não pode ser olvidada em prol de um "gigantismo absorvedor" do júri. ${ }^{78}$

Percebe-se, assim, que o in dubio pro societate é, no máximo, uma explicação equivocada e imprecisa do juízo de admissibilidade realizado na pronúncia. É ainda insatisfatória por desvirtuar o resultado da valoração das provas no juízo da acusação e obscurecer a carga de prova que incumbe ao órgão da acusação nessa etapa procedimental.

\footnotetext{
77 Nesse sentido: BONFIM, Edilson Mougenot. Júri. Do Inquérito ao plenário. 4. ed. São Paulo: Saraiva, 2012, p. 176; MIRABETE, Julio Fabbrini. Processo penal. 14. ed. São Paulo: Atlas, 2003, p. 487; GOMES, Márcio Schlee. Júri. Limites constitucionais da pronúncia. Porto Alegre: Sérgio Antonio Fabris Editor, 2010, p. 56; 75. Negando a dúvida em favor da sociedade, mas alcançando idêntica conclusão, Jader Marques argumenta que na pronúncia há a definição de prosseguimento para a etapa seguinte e por isso não é contra o réu e nem a favor da sociedade, mas "in dubio pro Júri" (MARQUES, Jader. Tribunal do júri. Considerações críticas à Lei 11.689/08. Porto Alegre: Livraria do Advogado, 2009, p. 64, destaque do original).

78 PORTO, Hermínio Alberto Marques. Júri. Procedimento e aspectos do julgamento. 12. ed. São Paulo: Saraiva, 2007, p. 32. Para Márcio Bártoli, trata-se de mera praxe judicial que encerra comodismo e serve como desculpa para não analisar o conjunto de provas (BÁRTOLI, Márcio Orlando. O princípio in dubio pro reo na pronúncia (jurisprudência comentada). Revista Brasileira de Ciências Criminais. São Paulo, v. 0, Esp. lançamento, dez. 1992, p. 132).
} 
Revista Eletrônica de Direito Processual - REDP.

Rio de Janeiro. Ano 15. Volume 22. Número 2. Maio a Agosto de 2021

Periódico Quadrimestral da Pós-Graduação Stricto Sensu em Direito Processual da UERJ

Patrono: José Carlos Barbosa Moreira (in mem.). ISSN 1982-7636. pp. 268-301

www.redp.uerj.br

A pronúncia deve ser buscada a partir da suficiência de seus requisitos, o que é diferente de estabelecer regra de julgamento contra o acusado para o caso de eventual dúvida. ${ }^{79}$ Se um dos requisitos não estiver presente, isto é, havendo dúvida sobre a presença de quaisquer deles, a solução a ser dada é a impronúncia.

Como explica Guilherme Brenner Lucchesi, a carga da prova que se atribui ao órgão acusatório é dinâmica. Isso quer dizer que não se exige do órgão de acusação a comprovação cabal da culpa do acusado logo no início do processo. Por outro lado, não gera o in dubio pro societate, mas justamente o contrário, ou seja, vige do in dubio pro reo desde o início do processo, pois " $O$ que pode variar é a quantidade e a qualidade da prova necessária para que a acusação possa obter uma decisão judicial favorável, havendo-se que modular a carga de prova nesse sentido." 80

$\mathrm{O}$ alto potencial retórico perpetua a incompreensão da real amplitude dos requisitos formais da pronúncia e a adoção de seus critérios de efetividade, haja vista: i) incentivar implicitamente a equiparação entre prova e elementos de informação; ii) não diferenciar o juízo de certeza para a materialidade do juízo de probabilidade para a autoria; iii) favorecer o exame impreciso e sem parâmetros mínimos das qualificadoras e causas de aumento; iv) não enfrentar a diferença de gradação da probabilidade para a autoria em comparação com o recebimento da denúncia.

\section{Conclusão}

O presente estudo buscou apontar diretrizes para tornar mais efetiva e factível a função de garantia da pronúncia contra acusações temerárias.

No rito bifásico do júri, o juízo de admissibilidade da acusação é progressivo e passa por duas etapas. A primeira é o recebimento da denúncia, onde se afere a justa causa com base nos resultados da investigação preliminar. A segunda diz respeito à decisão de pronúncia, onde se examina a evolução da proposta acusatória a partir das provas produzidas na instrução preliminar.

\footnotetext{
${ }^{79}$ BADARÓ, Gustavo Henrique Righi Ivahy. Ônus da prova no processo penal. São Paulo: RT, 2003, p. 391.

${ }^{80}$ LUCCHESI, Guilherme Brenner. O necessário desenvolvimento de standards probatórios compatíveis com o direito processual penal brasileiro. Revista Brasileira de Ciências Criminais. São Paulo, v. 27, n. 156, jun. 2019, p. 179-180.
} 
Revista Eletrônica de Direito Processual - REDP.

Rio de Janeiro. Ano 15. Volume 22. Número 2. Maio a Agosto de 2021

Periódico Quadrimestral da Pós-Graduação Stricto Sensu em Direito Processual da UERJ

Patrono: José Carlos Barbosa Moreira (in mem.). ISSN 1982-7636. pp. 268-301

www.redp.uerj.br

A pronúncia tem como requisitos formais a certeza da materialidade do fato e a existência de indícios suficientes de autoria ou de participação.

A expressão "indícios" de autoria não significa prova indireta, mas sim prova atenuada, dotada de eficácia persuasiva mais leve, com aptidão para gerar um juízo de probabilidade, mas não necessariamente um juízo de certeza.

A expressão materialidade do fato deve ser interpretada como existência do fato, independentemente de deixar ou não vestígios materiais. Ao contrário da autoria, exige-se prova apta a produzir um juízo de certeza.

O fato tido como qualificante integra a materialidade e requer um juízo de certeza. Já a análise valorativa-subsuntiva para fins de enquadramento do fato considerado como qualificante ao tipo legal da qualificadora se satisfaz com um juízo de possibilidade.

A imposição legal de uma etapa adicional judicializada para verificação da admissibilidade da acusação tem como consequência a valoração apenas de elementos produzidos em contraditório contemporâneo de partes, ressalvadas as provas não repetíveis, antecipadas, cautelares e a prova pré-constituída.

A identidade física do juiz é aplicável ao juízo da acusação, pois a ampla produção de provas resulta na mesma ratio justificadora presente no procedimento comum.

Apesar da ausência de lei no direito brasileiro sobre um standard de prova específico para a decisão de pronúncia, a construção teórica dos modelos de constatação serve como auxílio hermenêutico na definição da suficiência dos indícios de autoria.

O juízo de admissibilidade da pronúncia é superior ao do recebimento da denúncia em três pontos: i) exige elevada probabilidade em relação à autoria e certeza da existência do fato criminoso (maior quantidade de prova); ii) demanda elementos de prova produzidos em contraditório judicial (melhor qualidade de prova); iii) impõe a vinculação do juiz que presidiu a instrução preliminar para a emissão da decisão de admissibilidade (análise das provas por quem participou diretamente dos atos instrutórios).

O in dubio pro societate é uma tentativa imprecisa e imprudente de explicar o juízo de admissibilidade realizado na pronúncia. $\mathrm{O}$ alto potencial retórico empobrece a correta identificação dos requisitos formais e favorece a prolação de decisões desatentas aos critérios de efetividade aplicáveis à pronúncia. 


\section{REFERÊNCIAS}

ABIÁN, Rosario Herrera. La inmediación como garantía procesal (en el proceso civil y en el proceso penal). Granada: Editorial Comares, 2006.

ALMEIDA, Joaquim Canuto Mendes de. Princípios fundamentais do processo penal. São Paulo: Revista dos Tribunais, 1973.

ANTONINI, José Roberto. Júri. Garantia individual. Boletim IBCCRIM. São Paulo, v. 18, n. 210, p. 18, nov. 2010.

AQUINO, Álvaro Antônio Sagulo Borges de. A função garantidora da pronúncia. Rio de Janeiro: Lumen Juris, 2004.

BADARÓ, Gustavo Henrique Righi Ivahy. Ônus da prova no processo penal. São Paulo: Revista dos Tribunais, 2003.

BADARÓ, Gustavo Henrique Righi Ivahy. Juiz natural no processo penal. São Paulo: Revista dos Tribunais, 2014.

BADARÓ, Gustavo Henrique Righi Ivahy. Prisão em flagrante delito e liberdade provisória no Código de Processo Penal: origens, mudanças e futuro de um complicado relacionamento. In: MALAN, Diogo; MIRZA, Flávio (coord.). 70 anos do Código de Processo Penal brasileiro. Balanço e perspectivas de reforma. Rio de Janeiro: Lumen Juris, 2011, p. 171-197.

BADARÓ, Gustavo Henrique Righi Ivahy. Tribunal do júri. Lei 11.689, de 09.06.2008. In: MOURA, Maria Thereza Rocha de Assis (coord.). As reformas no processo penal. São Paulo: Revista dos Tribunais, 2008, p. 50-245.

BADARÓ, Gustavo Henrique Righi Ivahy. Editorial dossiê "Prova penal: fundamentos epistemológicos e jurídicos”. Revista Brasileira de Direito Processual Penal. Porto Alegre, vol. 4, n. 1, p. 43-80, jan./abr. 2018. https://doi.org/10.22197/rbdpp.v4i1.138.

BADARÓ, Gustavo Henrique Righi Ivahy. Epistemologia judiciária e prova penal. São Paulo: Revista dos Tribunais, 2019.

BÁRTOLI, Márcio Orlando. O princípio in dubio pro reo na pronúncia (jurisprudência comentada). Revista Brasileira de Ciências Criminais. São Paulo, v. 0, Esp. lançamento, p. 126-132, dez. 1992. 
Revista Eletrônica de Direito Processual - REDP.

Rio de Janeiro. Ano 15. Volume 22. Número 2. Maio a Agosto de 2021

Periódico Quadrimestral da Pós-Graduação Stricto Sensu em Direito Processual da UERJ

Patrono: José Carlos Barbosa Moreira (in mem.). ISSN 1982-7636. pp. 268-301

www.redp.uerj.br

BÁRTOLI, Márcio Orlando; PANZERI, André. Comentários ao artigo 121. In: FRANCO, Alberto Silva; STOCO, Rui (coord.). Código Penal e sua interpretação. Doutrina e jurisprudência. 8. ed. São Paulo: Revista dos Tribunais, 2007.

BONFIM, Edilson Mougenot. Júri. Do Inquérito ao plenário. 4. ed. São Paulo: Saraiva, 2012.

CAMPOS, Walfredo Cunha. Tribunal do júri. 3. ed. São Paulo: Atlas, 2014.

CANO, Leandro Jorge Bittencourt; ANTUNES, Rodrigo Merli; DOMINGUES, Alexandre de Sá. O tribunal do júri na visão do juiz, do promotor e do advogado. Questões práticas fundamentais. Versão compacta. São Paulo: Atlas, 2014.

CORRÊA, Luciana Perpétua. Procedimento especial do júri - não aplicação do artigo 155 do Código de Processo Penal - Possibilidade da decisão de pronúncia embasar-se em provas produzidas em fase inquisitorial. De Jure. Revista Jurídica do Ministério Público do Estado de Minas Gerais, Belo Horizonte, v. 11, n. 18, p. 202-216., jan./jun. 2012.

ESPÍNOla FILHO, Eduardo. Código de Processo Penal brasileiro anotado. v. IV. 5. ed. Rio de Janeiro: Editora Rio, 1976.

FERNANDES, Scarance Antonio. Teoria geral do procedimento e o procedimento no processo penal. São Paulo: Revista dos Tribunais, 2005.

GIACOMOLLI, Nereu José. Reformas (?) do processo penal. Considerações críticas. Rio de Janeiro: Lumen Juris, 2008.

GOMES, Décio Alonso. Prova e imediação no processo penal. Salvador: Juspodivm, 2016

GOMES FILHO, Antonio Magalhães. A motivação das decisões penais. São Paulo: Revista dos Tribunais, 2013.

GOMES, Márcio Schlee. Júri. Limites constitucionais da pronúncia. Porto Alegre: Sérgio Antonio Fabris Editor, 2010.

GOULART, Fábio Rodrigues. Tribunal do júri. Aspectos críticos relacionados à prova. São Paulo: Atlas, 2008.

GRECO FILHO, Vicente. Questões polêmicas sobre a pronúncia. In: TUCCI, Rogério Lauria (coord.). Tribunal do júri. Estudo sobre a mais democrática instituição jurídica brasileira. São Paulo: Saraiva, 1999, p. 117-126. 
Revista Eletrônica de Direito Processual - REDP.

Rio de Janeiro. Ano 15. Volume 22. Número 2. Maio a Agosto de 2021

Periódico Quadrimestral da Pós-Graduação Stricto Sensu em Direito Processual da UERJ

Patrono: José Carlos Barbosa Moreira (in mem.). ISSN 1982-7636. pp. 268-301

www.redp.uerj.br

GRINOVER, Ada Pellegrini. O conteúdo da garantia do contraditório. In: Novas tendências do direito processual: de acordo com a Constituição de 1988. Rio de Janeiro: Forense Universitária, 1990, p. 19-44.

HUngria, Nelson; FRAGOSO, Heleno Claudio. Comentários ao Código Penal. Arts.

121 a 136. Volume V. 5. ed. Rio de Janeiro: Forense, 1979.

IRIBURE JÚNIOR, Hamilton da Cunha. A pronúncia no procedimento do tribunal do júri brasileiro. 562f. Tese (Doutorado em Direito). Pontifícia Universidade Católica de São Paulo. São Paulo, 2008.

JARDIM, Afrânio Silva. Direito processual penal. 5. ed. Rio de Janeiro: Forense, 1995.

KARAM, Maria Lúcia. A admissibilidade da acusação e a pronúncia. Fascículos de Ciências Penais. Porto Alegre, v. 6, n. 1, p. 129-132, jan./fev. 1993. Disponível em: http://201.23.85.222/biblioteca/index.asp?codigo_sophia=52152. Acesso em: 13 de outubro de 2019.

KNIJNIK, Danilo. A prova nos juízos cível, penal e tributário. Rio de Janeiro: Forense, 2007.

LOPES JÚNIOR, Aury. Direito processual penal e sua conformidade constitucional. v.

2. 6. ed. Rio de Janeiro: Lumen Juris, 2011.

LUCCHESI, Guilherme Brenner. O necessário desenvolvimento de standards probatórios compatíveis com o direito processual penal brasileiro. Revista Brasileira de Ciências Criminais. São Paulo, v. 27, n. 156, p. 165-188, jun. 2019.

MARQUES, Jader. Tribunal do júri. Considerações críticas à Lei 11.689/08. Porto Alegre: Livraria do Advogado, 2009.

MARQUES, José Frederico. A instituição do júri. São Paulo: Saraiva, 1963.

MARQUES, Jose Frederico. Encerramento da formação da culpa no processo penal do júri. In: Estudos de direito e processo penal em homenagem a Nelson Hungria. Rio de Janeiro: Forense. 1962.

MARQUES, José Frederico. Notas e apontamentos sobre o júri. Revista de Jurisprudência do Tribunal de Justiça do Estado de São Paulo. São Paulo: Lex. vol. IX, p. 12-15, abril, maio e junho de 1969.

MIRABETE, Julio Fabbrini. Processo penal. 14. ed. São Paulo: Atlas, 2003. 
Revista Eletrônica de Direito Processual - REDP.

Rio de Janeiro. Ano 15. Volume 22. Número 2. Maio a Agosto de 2021

Periódico Quadrimestral da Pós-Graduação Stricto Sensu em Direito Processual da UERJ

Patrono: José Carlos Barbosa Moreira (in mem.). ISSN 1982-7636. pp. 268-301

www.redp.uerj.br

MOURA, Maria Thereza Rocha de Assis. Justa causa para a ação penal. Doutrina e jurisprudência. São Paulo: Revista dos Tribunais, 2001.

NARDELLI, Marcella Mascarenhas. A prova no tribunal do júri. Uma abordagem racionalista. Rio de Janeiro: Lumen Juris, 2019.

NASSIF, Aramis. O novo júri brasileiro. Porto Alegre: Livraria do Advogado, 2009.

NOGUEIRA, Rafael Fecury. A decisão de pronúncia no processo penal brasileiro: valoração da prova e limites à motivação. Rio de Janeiro: Lumen Juris, 2018.

NORONHA, Edgard Magalhães. Curso de direito processual penal. 16. ed. São Paulo: Saraiva, 1984.

NUCCI, Guilherme de Souza. Tribunal do júri. 3. ed. São Paulo: Revista dos Tribunais, 2012.

OLIVEIRA, Vitor Eduardo Tavares de. A impossibilidade de pronúncia com base nos elementos de informação do inquérito. In: PASSADORE, Bruno de Almeida; COSTA, Renata Tavares da; OLIVEIRA, Vitor Eduardo Tavares de (coord.). O tribunal do júri e a Defensoria Pública. Florianópolis: Tirant lo Blanch, 2018, p. 105-120.

PALMA, Andrea Galhardo. Breve análise comparativa dos modelos de valoração e constatação da prova penal - standards probatórios - no Brasil, nos EUA e na Itália: crítica à regra beyond any reasonable doubt ou oltre ragionevole dubbio (além da dúvida razoável). In: ONODERA, Marcus Vinicius Kiyoshi; FILIPPO, Thiago Baldani Gomes De (coord.). Brasil e EUA: temas de direito comparado. São Paulo: Escola Paulista da Magistratura, 2017, p. 287-338.

PERES, César. Sentença de pronúncia: in dubio pro societate. Boletim IBCCRIM. São Paulo, v. 12, n. 146, p. 14-15, jan. 2005.

PITOMBO, Sergio Marcos de Moraes. Pronúncia e o "in dubio pro societate". Revista da Escola Paulista da Magistratura. São Paulo, ano 4, n. 1, p. 09-23, janeiro/junho de 2003.

PORTO, Hermínio Alberto Marques. Júri. Procedimento e aspectos do julgamento. 12. ed. São Paulo: Saraiva, 2007. 
Revista Eletrônica de Direito Processual - REDP.

Rio de Janeiro. Ano 15. Volume 22. Número 2. Maio a Agosto de 2021

Periódico Quadrimestral da Pós-Graduação Stricto Sensu em Direito Processual da UERJ

Patrono: José Carlos Barbosa Moreira (in mem.). ISSN 1982-7636. pp. 268-301

www.redp.uerj.br

QUEIJO, Maria Elizabeth; RASSI, João Daniel. Questões polêmicas atinentes ao novo procedimento do Tribunal do Júri. In: MARZAGÃO JÚNIOR, Laerte I. (coord.).

Homicídio crime rei. São Paulo: Quartier Latin, 2009, p. 182-207.

RODRÍGUEZ, Nicolás Cabezudo. Del principio de inmediación, sus excepciones y los instrumentos tecnológicos. Valencia: Tirant lo Blanch, 2010.

ROSA, Borges da. Comentários ao Código de Processo Penal. Atualizado por Angelito

A. Aiquel. 3. ed. São Paulo: Revista dos Tribunais, 1982.

SILVA, Marco Antonio Marques da. A vinculação do juiz no processo penal. São Paulo: Saraiva, 1993.

TASSE, Adel El. Júri. Teoria e prática. Curitiba: Juruá, 2018.

TONINI, Paolo. A prova no processo penal italiano. Tradução de Alexandra Martins e Daniela Mróz. São Paulo: RT, 2002.

TORRES, José Henrique Rodrigues. O júri garantista. Boletim IBCCRIM. São Paulo, n. 226, v. 19, p. 07-08, setembro de 2011.

TORRES, José Henrique Rodrigues. Quesitação: a importância da narrativa do fato na imputação inicial, na pronúncia, no libelo e nos quesitos. In: TUCCI, Rogério Lauria (coord.). Tribunal do júri: estudo sobre a mais democrática instituição jurídica brasileira. São Paulo: Revista dos Tribunais, 1999, p. 211-257.

TUBENCHLAK, James. Tribunal do júri. Contradições e soluções. 4. ed. São Paulo: Saraiva, 1994.

VIDAL, Luís Fernando Camargo de Barros. Homicídio qualificado e procedimento do júri.

Revista Brasileira de Ciências Criminais. São Paulo, v. 8, n. 32, p. 94-119, out./dez., 2000.

ZVEIBIL, Daniel Guimarães. O arbítrio palavreado no processo penal: breve ensaio sobre a pronúncia e o "in dubio pro societate". Revista Brasileira de Ciências Criminais. São Paulo, v. 16, n. 74, p. 281-298, set./out. 2008. 